\title{
Carbon Dioxide Reduction at Low-Valent Molybdenum Terphenyl Diphosphine Complexes with Dihydrogen and Silanes: Reductant Identity Dictates Mechanism
}

Joshua A. Buss ${ }^{\dagger+}$, Naoki Shida ${ }^{*}+$, Tianyi He, and Theodor Agapie*

Division of Chemistry and Chemical Engineering, California Institute of Technology, 1200 East

California Boulevard MC 127-72, Pasadena, California 91125, United States

\section{Corresponding Author}

*agapie@caltech.edu

\section{Present Addresses}

${ }^{\dagger}$ Department of Chemistry, University of Michigan, 930 North University Avenue, Ann Arbor, Michigan 48109, United States

**Department of Chemistry and Life Science, Yokohama National University, 79-5 Tokiwadai, Hodogaya-ku, Yokohama, Kanagawa 240-8501, Japan

\section{Author Contributions}

These authors contributed equally.

\section{Supporting Information}

\section{Contents}

Experimental Details

General Considerations $\quad$ S3

$\begin{array}{ll}\text { Synthesis of } 4 & \text { S3 }\end{array}$

$\begin{array}{ll}\text { Synthesis of } \mathbf{5} & \text { S4 }\end{array}$

$\begin{array}{ll}\text { Synthesis of } 6 & \text { S4 }\end{array}$

In Situ Preparation of $9 \quad$ S5

NMR Spectra

Figure $\mathrm{S} 1-{ }^{1} \mathrm{H}$ NMR Spectrum of $\mathbf{4} \quad$ S6

Figure S2- ${ }^{31} \mathrm{P}\left\{{ }^{1} \mathrm{H}\right\}$ NMR Spectrum of $4 \quad$ S6

Figure $\mathrm{S} 3-{ }^{1} \mathrm{H} /{ }^{1} \mathrm{H}$ COSY Spectrum of $4 \quad$ S6

$\begin{array}{ll}\text { Figure } \mathrm{S} 4-{ }^{1} \mathrm{H} \text { NMR Spectrum of } \mathbf{5} & \text { S7 }\end{array}$

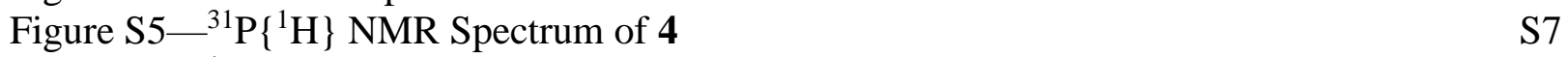

$\begin{array}{ll}\text { Figure S6- }{ }^{1} \mathrm{H} \text { NMR Spectrum of } 6 & \text { S8 }\end{array}$

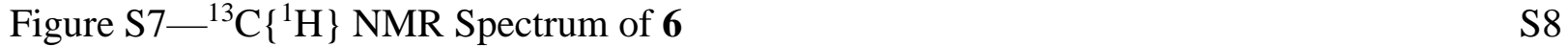

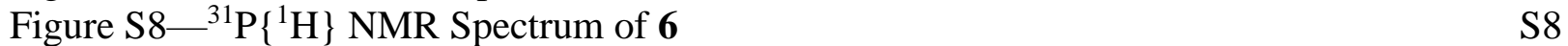

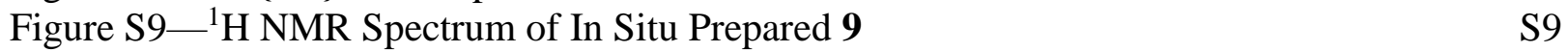

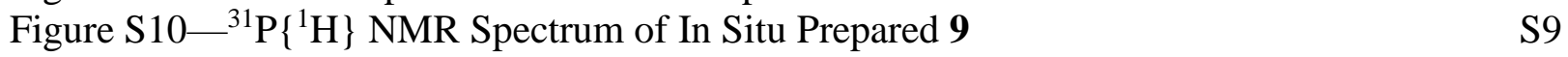

Silane Coordination Chemistry

Figure S11 ${ }^{31} \mathrm{P}\left\{{ }^{1} \mathrm{H}\right\}$ NMR Spectra of $\mathrm{PhMeSiH}_{2}$ Addition to 1 
Figure S12- ${ }^{1}$ H NMR Spectrum of In Situ Prepared 6'

$\mathrm{CO}_{2}$ Cleavage Kinetics in the Presence of $\mathrm{PhMeSiH}_{2}$

Figure $\mathrm{S} 13-\mathrm{CO}_{2}$ Cleavage Rates as a Function of $\left[\mathrm{PhMeSiH}_{2}\right]$

$\mathrm{S} 12$

Figure S14-Substrate Inhibition Kinetics Plot

GC/MS Data

Figure S15-NMR Spectra Monitoring C-O Cleavage

S13

Figure S16 - GC/MS Traces Identifying Silanol Formation

General Procedures for Catalytic Reactions

$\mathrm{CO}_{2}$ Hydrogenation Catalysis

S15

Formic Acid Dehydrogenation Catalysis

S15

Figure S17-Characteristic Gas Evolution Time-Course

S15

Figure S18-Analysis of Catalyst Decomposition

S16

Stoichiometric Reactivity Targeting Catalytic Intermediates

Figure S19-Formic Acid Addition to 1

Figure S20-Thermal Dehydrogenation of 4

S18

Figure S21-Additive Addition to 4

S18

Figure S22 - Independent Synthesis of 12

Figure S23-Protonation of Formate Hydride 4

S20

Figure S24-Protonation of Carboxylate Hydride 5

S21

Figure S25-Carboxylate Addition to Hydride Cation 12

Crystallographic Information

Refinement Details

S23

Tables S1-Crystal and Refinement Data for 5, 6, and 9

Figure S26-Structural Drawing of 5

S24

Figure S27-Structural Drawing of 6

S25

Figure S28-Structural Drawing of 9

S26

References

S27 


\section{General Considerations}

Unless otherwise specified, all operations were carried out in an MBraun drybox under a nitrogen atmosphere or using standard Schlenk and vacuum line techniques. Solvents for airand moisture-sensitive reactions were dried over sodium benzophenone ketyl, calcium hydride, or by the method of Grubbs. ${ }^{1}$ Deuterated solvents were purchased from Cambridge Isotope Laboratories and vacuum transferred from sodium benzophenone ketyl $\left(\mathrm{C}_{6} \mathrm{D}_{6}\right)$ or $\mathrm{CaH}_{2}\left(\mathrm{CD}_{3} \mathrm{CN}\right)$. Solvents, once dried and degassed, were vacuum transferred directly prior to use or stored under inert atmosphere over $4 \AA$ molecular sieves. Molybdenum complexes 1, $\mathbf{2}$, and $\mathbf{3}$ were prepared and purified according to reported procedures. ${ }^{2-3}$ Unless indicated otherwise, all chemicals were obtained from standard commercial vendors and utilized as received. ${ }^{1} \mathrm{H},{ }^{13} \mathrm{C}\left\{{ }^{1} \mathrm{H}\right\}$, and ${ }^{31} \mathrm{P}\left\{{ }^{1} \mathrm{H}\right\}$ NMR spectra were recorded on Varian $400 \mathrm{MHz}$ or Varian INOVA-500 spectrometers with shifts reported in parts per million (ppm). ${ }^{1} \mathrm{H}$ and ${ }^{13} \mathrm{C}\left\{{ }^{1} \mathrm{H}\right\}$ NMR spectra are referenced to residual solvent peaks. ${ }^{41} \mathrm{P}\left\{{ }^{1} \mathrm{H}\right\}$ chemical shifts are referenced to external $85 \% \mathrm{H}_{3} \mathrm{PO}_{4}(0 \mathrm{ppm})$.

\section{Synthesis of 4}
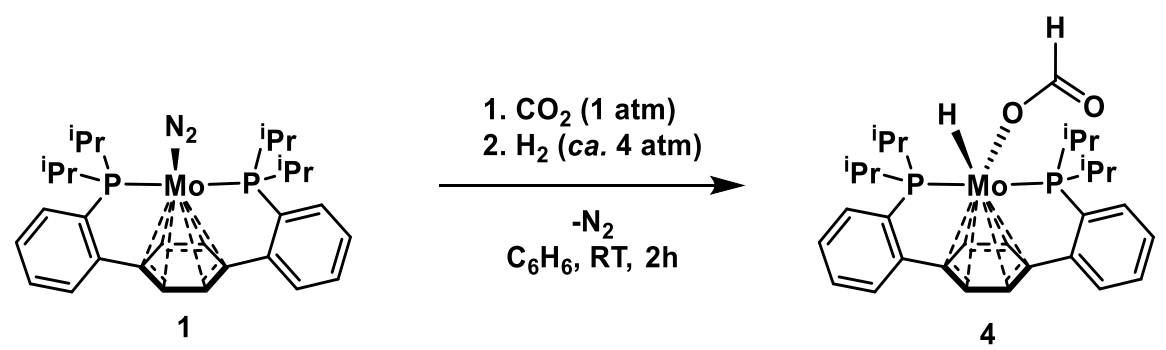

A brown/red solution of 1 (49.9 mg, $0.085 \mathrm{mmol})$ in $\mathrm{C}_{6} \mathrm{H}_{6}(3 \mathrm{~mL})$ was transferred to a Schlenk tube charged with a stir bar. The solution was degassed via three freeze-pump-thaw cycles. The headspace was backfilled with $1 \mathrm{~atm}$ of $\mathrm{CO}_{2}$ gas, enacting slight reddening of the solution. The Schlenk tube was sealed and then submerged in $\mathrm{LN}_{2}$, freezing the contents and condensing the $\mathrm{CO}_{2}$. It was then opened to 1 atm of $\mathrm{H}_{2}$ gas, maintaining the $-196{ }^{\circ} \mathrm{C}$ temperature. The flask was resealed and the contents were allowed to warm to ambient temperature with stirring for $2 \mathrm{~h}$. The now red solution was lyophilized in vacuo, giving 4 as a reddish brown powder. Dissolution of this complex for spectroscopic analysis showed speciation consistent with an equilibrium between complexes $\mathbf{1 - 4}$, dependent on the reaction vessel atmosphere. The cleanest samples were prepared by adapting the procedure described above for in situ generation of $\mathbf{4}$ in a J. Young style NMR tube. Attempts to grow single crystals from samples of $\mathbf{4}$ (prepared as described above) under an $\mathrm{N}_{2}$ atmosphere reproducibly returned crystalline samples of $1 .{ }^{1} \mathrm{H} \mathrm{NMR}\left(400 \mathrm{MHz}, \mathrm{C}_{6} \mathrm{D}_{6}, 23{ }^{\circ} \mathrm{C}\right) \delta: 8.90$ (s, $1 \mathrm{H}, \mathrm{OCHO}), 7.24$ (d, J = 7.07 Hz, 2H, aryl-H), 7.05-7.08 (br m, 2H, aryl-H), 6.99 (t, J = 7.46 Hz, 2H, aryl-H), $6.94(\mathrm{t}, \mathrm{J}=7.17 \mathrm{~Hz}, 2 \mathrm{H}$, aryl-H), $6.21(\mathrm{~s}, 2 \mathrm{H}$, central arene- $H), 3.59-3.62(\mathrm{~m}, 2 \mathrm{H}$, central arene$H$ ), 2.46-2.57 (m, 2H, CH(CH$\left.)_{2}\right), 2.35-2.46\left(\mathrm{~m}, 2 \mathrm{H}, \mathrm{CH}\left(\mathrm{CH}_{3}\right)_{2}\right), 1.81(\mathrm{t}, 1 \mathrm{H}, J=86.41 \mathrm{~Hz}, \mathrm{Mo}-H), 1.21-$ $1.27\left(\mathrm{~m}, 6 \mathrm{H}, \mathrm{CH}\left(\mathrm{CH}_{3}\right)_{2}\right), 0.94-1.05\left(\mathrm{~m}, 12 \mathrm{H}, \mathrm{CH}\left(\mathrm{CH}_{3}\right)_{2}\right), 0.80-0.85\left(\mathrm{~m}, 6 \mathrm{H}, \mathrm{CH}\left(\mathrm{CH}_{3}\right)_{2}\right) .{ }^{31} \mathrm{P}\left\{{ }^{1} \mathrm{H}\right\} \mathrm{NMR}(162$ $\left.\mathrm{MHz}, \mathrm{C}_{6} \mathrm{D}_{6}, 23{ }^{\circ} \mathrm{C}\right) \delta: 89.82$. 
Synthesis of 5
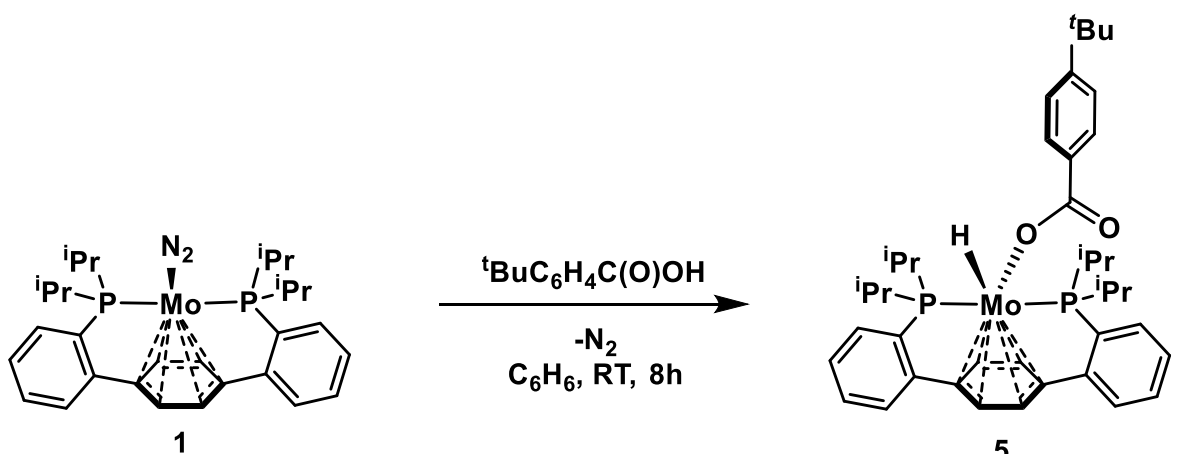

A $20 \mathrm{~mL}$ scintillation vial was charged with 1 (200 mg, $0.341 \mathrm{mmol}), \mathrm{C}_{6} \mathrm{H}_{6}(5 \mathrm{~mL})$, and ${ }^{t} \mathrm{BuC}_{6} \mathrm{H}_{4} \mathrm{C}(\mathrm{O}) \mathrm{OH}$ (73 mg, $0.408 \mathrm{mmol}$ ). The red solution was allowed to stir for $8 \mathrm{~h}$, at which time the vial contents were frozen solid in a $-35{ }^{\circ} \mathrm{C}$ freezer and the $\mathrm{C}_{6} \mathrm{H}_{6}$ lyophilized under reduced pressure, giving 5 as a red powder. $\mathrm{X}$-ray quality single crystals were grown via diffusion of pentane into a concentrated $\mathrm{C}_{6} \mathrm{H}_{6}$ solution of 5 . ${ }^{1} \mathrm{H}$ NMR $\left(400 \mathrm{MHz}, \mathrm{C}_{6} \mathrm{D}_{6}, 23{ }^{\circ} \mathrm{C}\right) \delta: 8.31(\mathrm{~d}, J=8.2 \mathrm{~Hz}, 2 \mathrm{H}$, aryl- $H), 7.28(\mathrm{t}, J=7.0 \mathrm{~Hz}, 2 \mathrm{H}$, aryl- $H), 7.03-$ $7.05(\mathrm{~m}, 2 \mathrm{H}$, aryl- $H$ ), 6.97 (t, $J=7.3 \mathrm{~Hz}, 2 \mathrm{H}$, aryl- $H$ ), 6.89 (t, $J=7.4 \mathrm{~Hz}, 2 \mathrm{H}$, aryl- $H$ ), 6.46 (v br, $2 \mathrm{H}$, central arene- $H)$, 3.61-3.64 (m, $2 \mathrm{H}$, central arene- $H), 2.60-2.64\left(\mathrm{~m}, 2 \mathrm{H}, \mathrm{CH}\left(\mathrm{CH}_{3}\right)_{2}\right), 2.44-53\left(\mathrm{~m}, 2 \mathrm{H}, \mathrm{CH}\left(\mathrm{CH}_{3}\right)_{2}\right)$, $2.10(\mathrm{t}, J=84.93 \mathrm{~Hz}, \mathrm{Mo}-\mathrm{H}), 1.34-1.39\left(\mathrm{~m}, 6 \mathrm{H}, \mathrm{CH}\left(\mathrm{CH}_{3}\right)_{2}\right), 0.96-1.01\left(\mathrm{~m}, 6 \mathrm{H}, \mathrm{CH}\left(\mathrm{CH}_{3}\right)_{2}\right), 0.75-0.80(\mathrm{~m}$, $\left.12 \mathrm{H}, \mathrm{CH}\left(\mathrm{CH}_{3}\right)_{2}\right) .{ }^{31} \mathrm{P}\left\{{ }^{1} \mathrm{H}\right\} \mathrm{NMR}\left(162 \mathrm{MHz}, \mathrm{C}_{6} \mathrm{D}_{6}, 23{ }^{\circ} \mathrm{C}\right) \delta: 89.61(\mathrm{~s})$.

Synthesis of 6

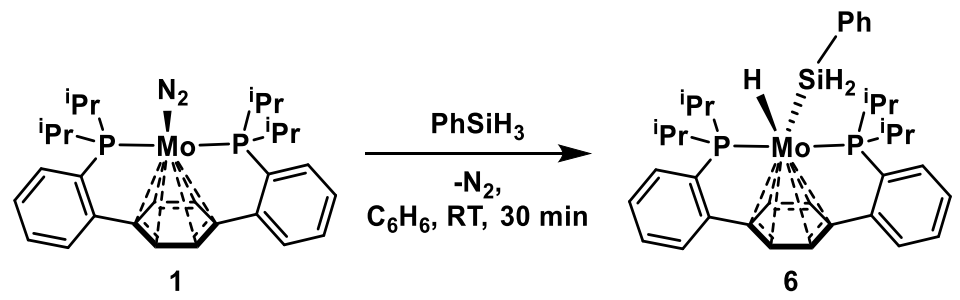

A brown/red solution of $1(61 \mathrm{mg}, 0.104 \mathrm{mmol})$ in benzene $(4 \mathrm{~mL})$ was transferred to a $20 \mathrm{~mL}$ scintillation vial, charged with a stir bar. With stirring, $\mathrm{PhSiH}_{3}(12.8 \mu \mathrm{L}, 0.104 \mathrm{mmol})$ was added via microsyringe, causing a lightening of the solution. Stirring continued for $30 \mathrm{~min}$. At that time, the solution was lyophilized under reduced pressure, providing 6 as a yellow/orange powder $(58.4 \mathrm{mg}, 0.088 \mathrm{mmol}, 85 \%)$. X-ray quality crystals were grown by chilling a saturated hexanes solution of $6\left(-35^{\circ} \mathrm{C}\right) .{ }^{1} \mathrm{H}$ NMR $\left(400 \mathrm{MHz}, \mathrm{C}_{6} \mathrm{D}_{6}, 23\right.$ $\left.{ }^{\circ} \mathrm{C}\right) \delta$ : 7.67-7.69 (m, $2 \mathrm{H}$, aryl- $\left.H\right), 7.33(\mathrm{~d}, J=7.3 \mathrm{~Hz}, 2 \mathrm{H}$, aryl- $H), 7.06-7.07(\mathrm{~m}, 3 \mathrm{H}$, aryl- $H)$, 6.97-7.00 (m, $2 \mathrm{H}$, aryl- $H), 6.88-6.94(\mathrm{~m}, 4 \mathrm{H}$, aryl- $H), 5.51(\mathrm{~s}, 2 \mathrm{H}, \mathrm{Si}-H), 4.59-4.62(\mathrm{~m}, 2 \mathrm{H}$, central arene- $H), 4.46(\mathrm{~s}, 2 \mathrm{H}$, central arene- $H)$, 2.13-2.23 (m, 2H, $\left.\mathrm{CH}\left(\mathrm{CH}_{3}\right)_{2}\right), 2.04-2.13\left(\mathrm{~m}, 2 \mathrm{H}, \mathrm{CH}\left(\mathrm{CH}_{3}\right)_{2}\right)$ 1.13-1.18 (m, 6H, $\left.\mathrm{CH}\left(\mathrm{CH}_{3}\right)_{2}\right), 0.92-1.08\left(\mathrm{~m}, 18 \mathrm{H}, \mathrm{CH}\left(\mathrm{CH}_{3}\right)_{2}\right),-3.13$ (t, $\left.J=43.41 \mathrm{~Hz}, 1 \mathrm{H}, \mathrm{Mo}-H\right) .{ }^{13} \mathrm{C}$ NMR $\left(101 \mathrm{MHz}, \mathrm{C}_{6} \mathrm{D}_{6}\right.$, $23{ }^{\circ} \mathrm{C}$ ) $\delta: 149.5-149.79(\mathrm{~m}$, aryl- $C$ ), 149.09 (vt. $J=12.35 \mathrm{~Hz}$, aryl-C), 146.96 (s, aryl-C), 136.60 (s, aryl$C$ ), 130.32 (s, aryl-C), 128.55 (br s, aryl-C), 127.60 (vt, $J=4.4 \mathrm{~Hz}$, aryl-C), 127.25 (s, aryl-C), 126.99 (s, aryl-C), 126.34 (vt, $J=2.0 \mathrm{~Hz}$, aryl- $C$ ), 97.93 (vt, $J=2.3 \mathrm{~Hz}$, central arene- $C$ ), 81.19 (s, central arene- $C$ ), 76.40 (s, central arene- $C$ ), $31.32\left(\mathrm{vt}, J=6.2 \mathrm{~Hz}, C \mathrm{H}\left(\mathrm{CH}_{3}\right)_{2}\right), 29.01-28.57\left(\mathrm{~m}, C \mathrm{H}_{(}\left(\mathrm{CH}_{3}\right)_{2}\right), 20.97$ (vt, $J=$ $\left.3.6 \mathrm{~Hz}, \mathrm{CH}\left(\mathrm{CH}_{3}\right)_{2}\right), 20.22\left(\mathrm{~s}, \mathrm{CH}\left(\mathrm{CH}_{3}\right)_{2}\right), 19.96\left(\mathrm{vt}, J=2.6 \mathrm{~Hz}, \mathrm{CH}\left(\mathrm{CH}_{3}\right)_{2}\right) .{ }^{31} \mathrm{P}\left\{{ }^{1} \mathrm{H}\right\} \mathrm{NMR}\left(162 \mathrm{MHz}, \mathrm{C}_{6} \mathrm{D}_{6}\right.$, $\left.23{ }^{\circ} \mathrm{C}\right) \delta: 70.79(\mathrm{~d}, J=8.22 \mathrm{~Hz})$. 
Preparation of 9

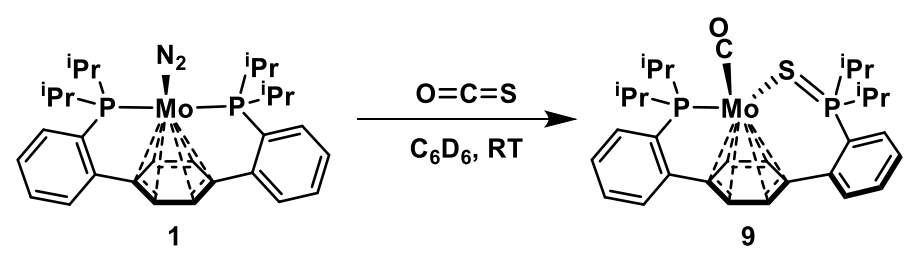

A J. Young style NMR tube was charged with a deep red solution of 1 ( $25 \mathrm{mg}, 0.043 \mathrm{mmol})$ in $\mathrm{C}_{6} \mathrm{D}_{6}(0.5$ $\mathrm{mL})$. The reaction was degassed via three freeze-pump-thaw cycles and then backfilled with OCS (1 atm.). The contents of the tube were mixed by inversion for $15 \mathrm{~min}$, forming $\mathbf{9}$. Complex 9 was never isolated, but X-ray quality single crystals were obtained by allowing the J. Young tube to stand, unperturbed, for 12 h. ${ }^{1} \mathrm{H}$ NMR $\left(400 \mathrm{MHz}, \mathrm{C}_{6} \mathrm{D}_{6}, 23{ }^{\circ} \mathrm{C}\right) \delta: 7.52-7.56(\mathrm{~m}, 1 \mathrm{H}$, aryl-H), 7.46-7.49 (m, 1H, aryl-H), 7.19-7.23 (m, $1 \mathrm{H}$, aryl-H), 6.98-7.04 (m, 3H, aryl- $H$ ), 6.86 (br t, $J=6.6 \mathrm{~Hz}, 1 \mathrm{H}$, aryl- $H), 6.75$ (t, $J=8.5 \mathrm{~Hz}, 1 \mathrm{H}$, aryl- $H$ ), $4.79(\mathrm{~d}, J=4.6 \mathrm{~Hz}, 1 \mathrm{H}$, central arene- $H), 4.71(\mathrm{~d}, J=6.5 \mathrm{~Hz}, 1 \mathrm{H}$, central arene- $H), 4.03(\mathrm{~d}, J=6.6 \mathrm{~Hz}, 1 \mathrm{H}$, central arene- $H), 3.83(\mathrm{~d}, J=4.7 \mathrm{~Hz}, 1 \mathrm{H}$, central arene- $H), 3.45-2.60\left(\mathrm{~m}, 2 \mathrm{H}, \mathrm{CH}\left(\mathrm{CH}_{3}\right)_{2}\right), 2.23-2.35(\mathrm{~m}$, $\left.1 \mathrm{H}, \mathrm{CH}\left(\mathrm{CH}_{3}\right)_{2}\right), 1.80-1.91\left(\mathrm{~m}, 1 \mathrm{H}, \mathrm{CH}\left(\mathrm{CH}_{3}\right)_{2}\right), 1.37-1.42\left(\mathrm{~m}, 3 \mathrm{H}, \mathrm{CH}\left(\mathrm{CH}_{3}\right)_{2}\right), 1.18-1.27(\mathrm{~m}, 6 \mathrm{H}$, $\left.\mathrm{CH}\left(\mathrm{CH}_{3}\right)_{2}\right), 1.00-1.12\left(\mathrm{~m}, 6 \mathrm{H}, \mathrm{CH}\left(\mathrm{CH}_{3}\right)_{2}\right), 0.77-0.95\left(\mathrm{~m}, 9 \mathrm{H}, \mathrm{CH}\left(\mathrm{CH}_{3}\right)_{2}\right) .{ }^{31} \mathrm{P}\left\{{ }^{1} \mathrm{H}\right\} \mathrm{NMR}\left(162 \mathrm{MHz}, \mathrm{C}_{6} \mathrm{D}_{6}\right.$, $\left.23{ }^{\circ} \mathrm{C}\right) \delta: 88.64(\mathrm{~d}, J=17.7 \mathrm{~Hz}, \mathrm{Mo}-P), 59.57(\mathrm{~d}, J=17.8 \mathrm{~Hz}, \mathrm{P}=S)$. 


\section{NMR Spectra of Complexes}

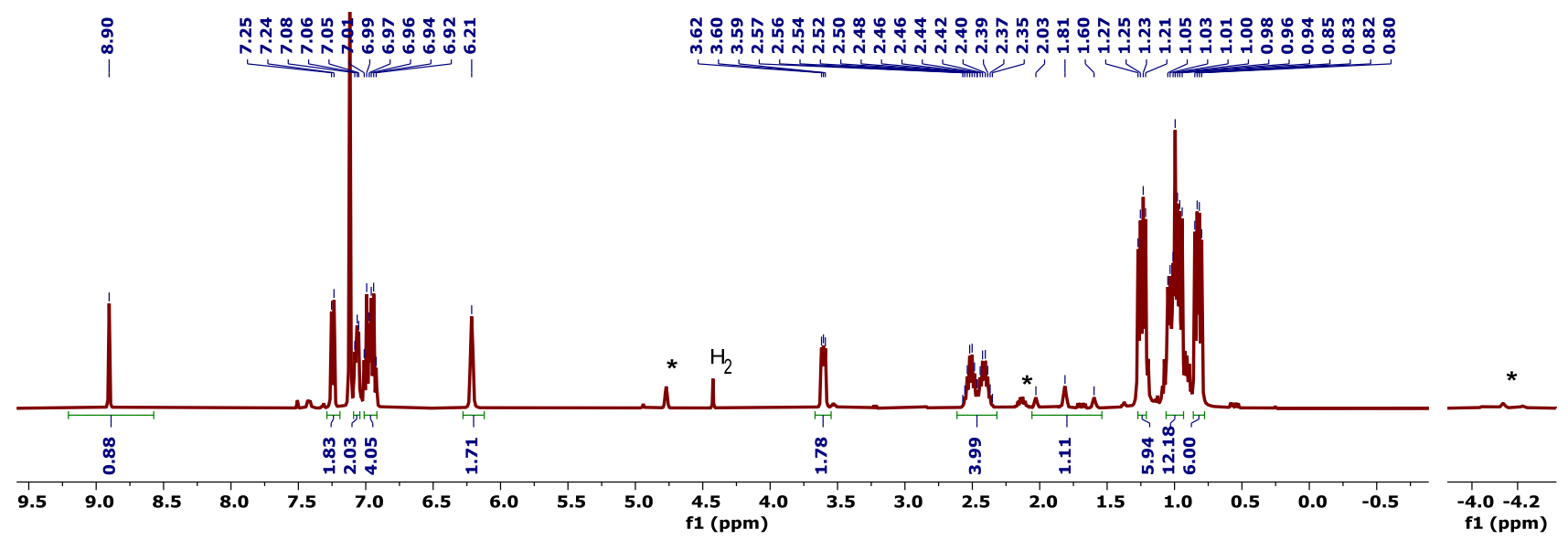

Figure S1. ${ }^{1} \mathrm{H}$ NMR Spectrum $\left(400 \mathrm{MHz}, \mathrm{C}_{6} \mathrm{D}_{6}, 23{ }^{\circ} \mathrm{C}\right)$ of 4 . When complex 4 is prepared under an excess of $\mathrm{H}_{2}$ gas, dihydride $\mathbf{2}$ is observed as a minor reaction component. The resonances associated with this complex are designated with asterisks above.

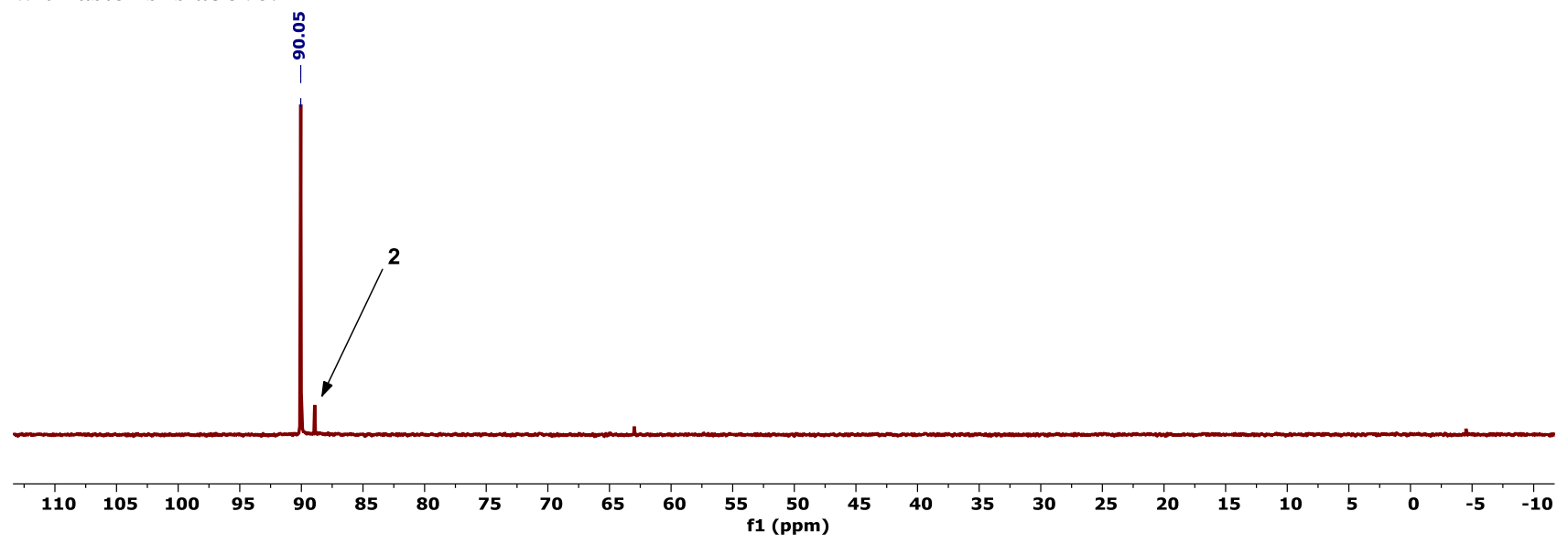

Figure S2. ${ }^{31} \mathrm{P}\left\{{ }^{1} \mathrm{H}\right\}$ NMR Spectrum $\left(162 \mathrm{MHz}, \mathrm{C}_{6} \mathrm{D}_{6}, 23{ }^{\circ} \mathrm{C}\right)$ of 4 . When complex 4 is prepared under an excess of $\mathrm{H}_{2}$ gas, dihydride 2 is observed as a minor reaction component and is appropriately labeled in the spectrum above.

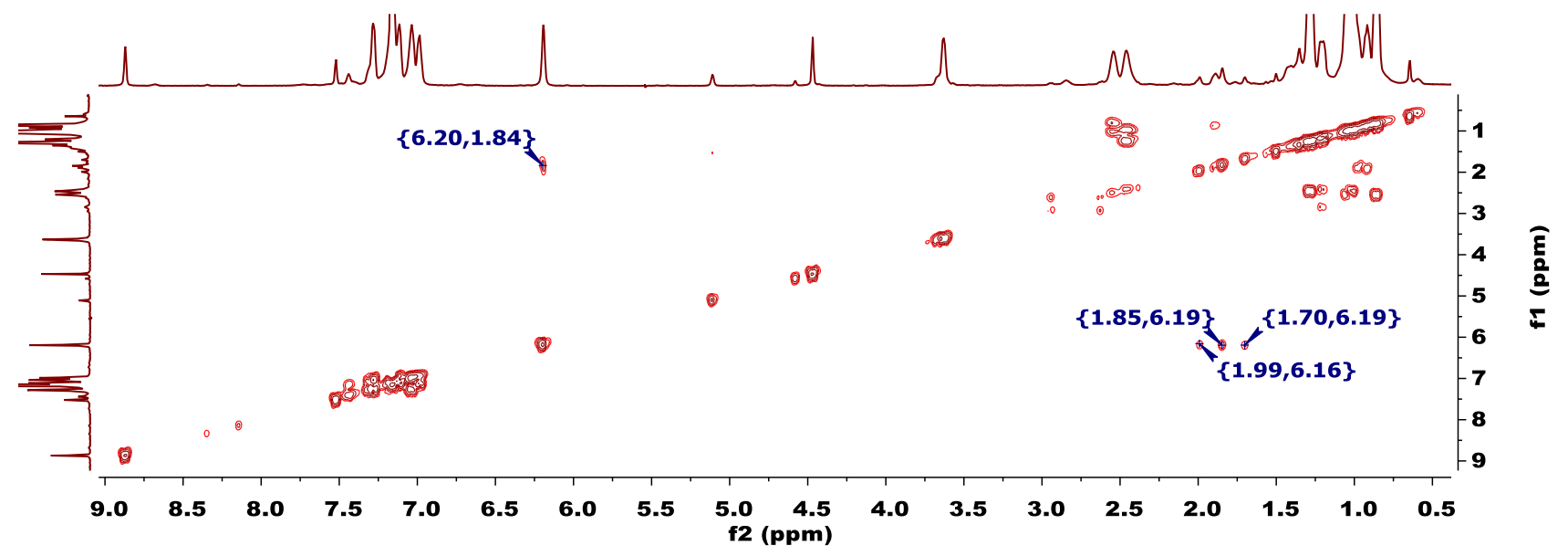

Figure S3. Partial ${ }^{1} \mathrm{H} /{ }^{1} \mathrm{H}$ COSY NMR spectrum $\left(600 \mathrm{MHz}, \mathrm{C}_{6} \mathrm{D}_{6}, 23{ }^{\circ} \mathrm{C}\right)$ of complex 4 . The correlation between the hydride resonance at $1.85 \mathrm{ppm}$ and that of the central arene proton at $6.20 \mathrm{ppm}$ is highlighted. 


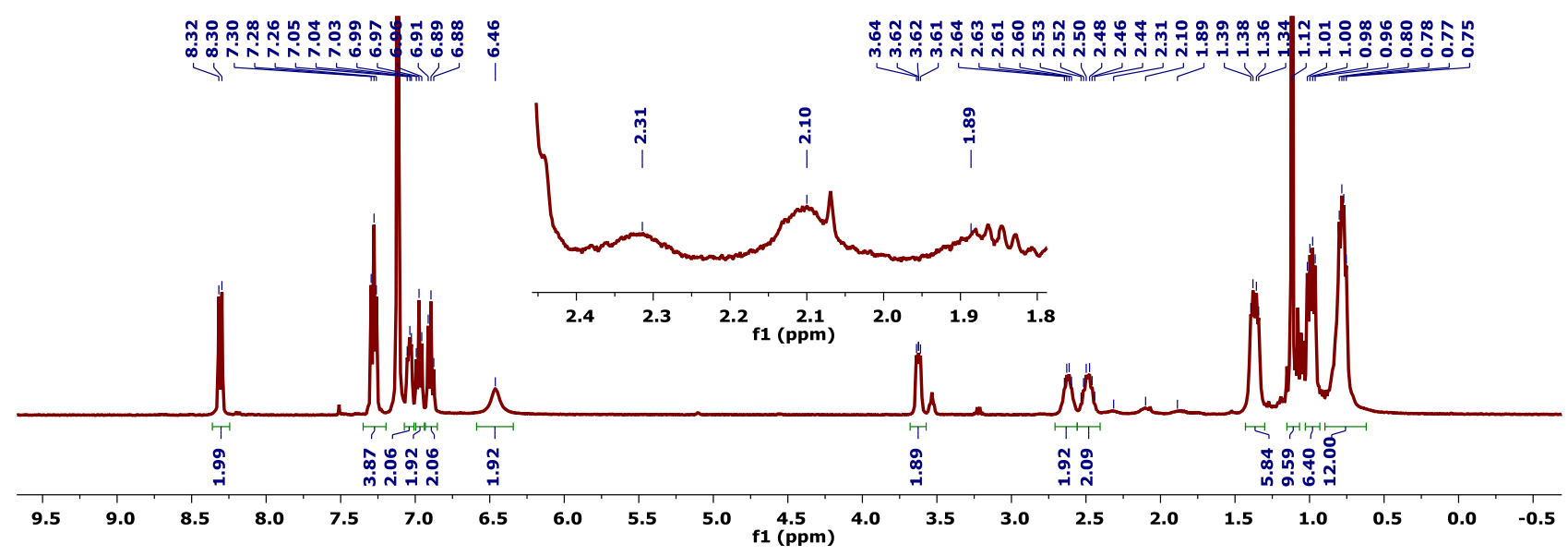

Figure S4. ${ }^{1} \mathrm{H}$ NMR Spectrum $\left(400 \mathrm{MHz}, \mathrm{C}_{6} \mathrm{D}_{6}, 23^{\circ} \mathrm{C}\right)$ of 5 . The inset shows an enlargement of the hydride resonance at $2.10 \mathrm{ppm}$.

$$
\text { - }
$$

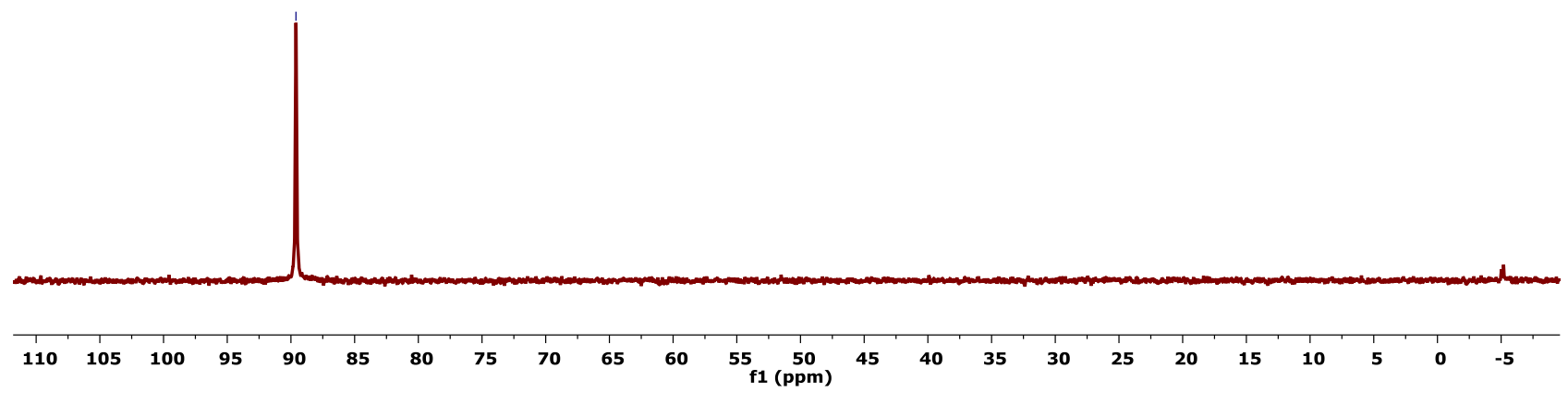

Figure S5. ${ }^{31} \mathrm{P}\left\{{ }^{1} \mathrm{H}\right\}$ NMR Spectrum $\left(162 \mathrm{MHz}, \mathrm{C}_{6} \mathrm{D}_{6}, 23{ }^{\circ} \mathrm{C}\right)$ of 5 . 


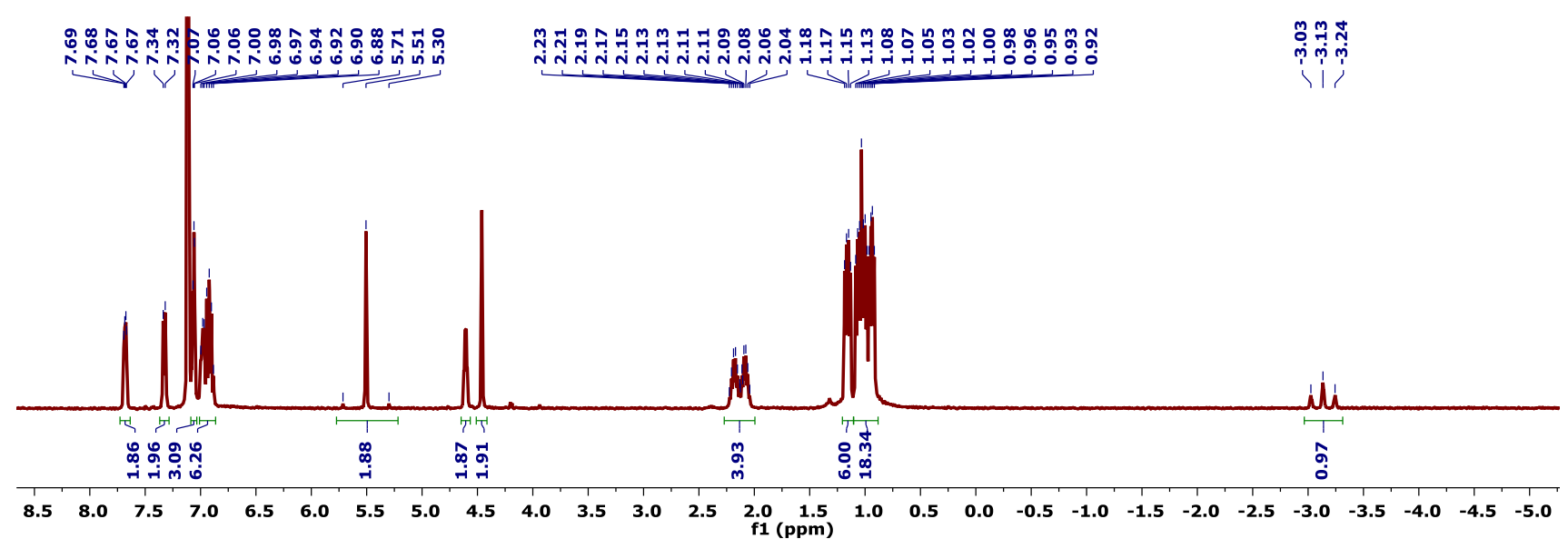

Figure S6. ${ }^{1} \mathrm{H}$ NMR Spectrum ( $\left.400 \mathrm{MHz}, \mathrm{C}_{6} \mathrm{D}_{6}, 23{ }^{\circ} \mathrm{C}\right)$ of 6 .

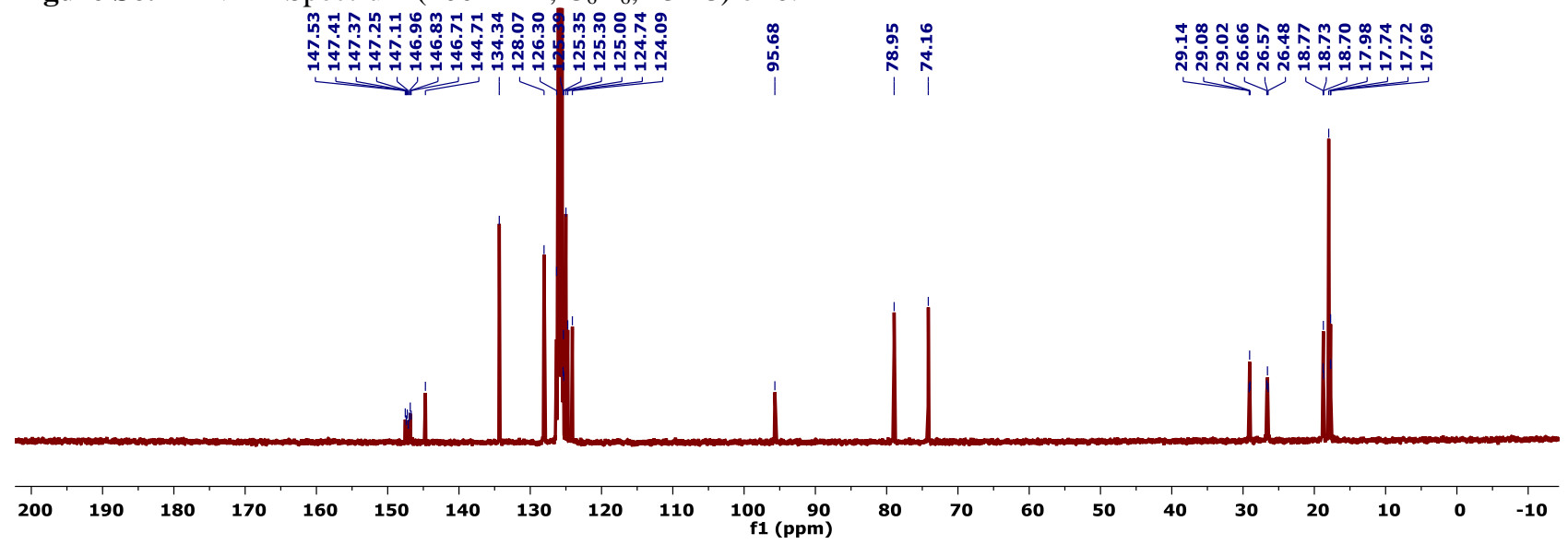

Figure S7. ${ }^{13} \mathrm{C}\left\{{ }^{1} \mathrm{H}\right\}$ NMR Spectrum $\left(101 \mathrm{MHz}, \mathrm{C}_{6} \mathrm{D}_{6}, 23{ }^{\circ} \mathrm{C}\right)$ of 6 .
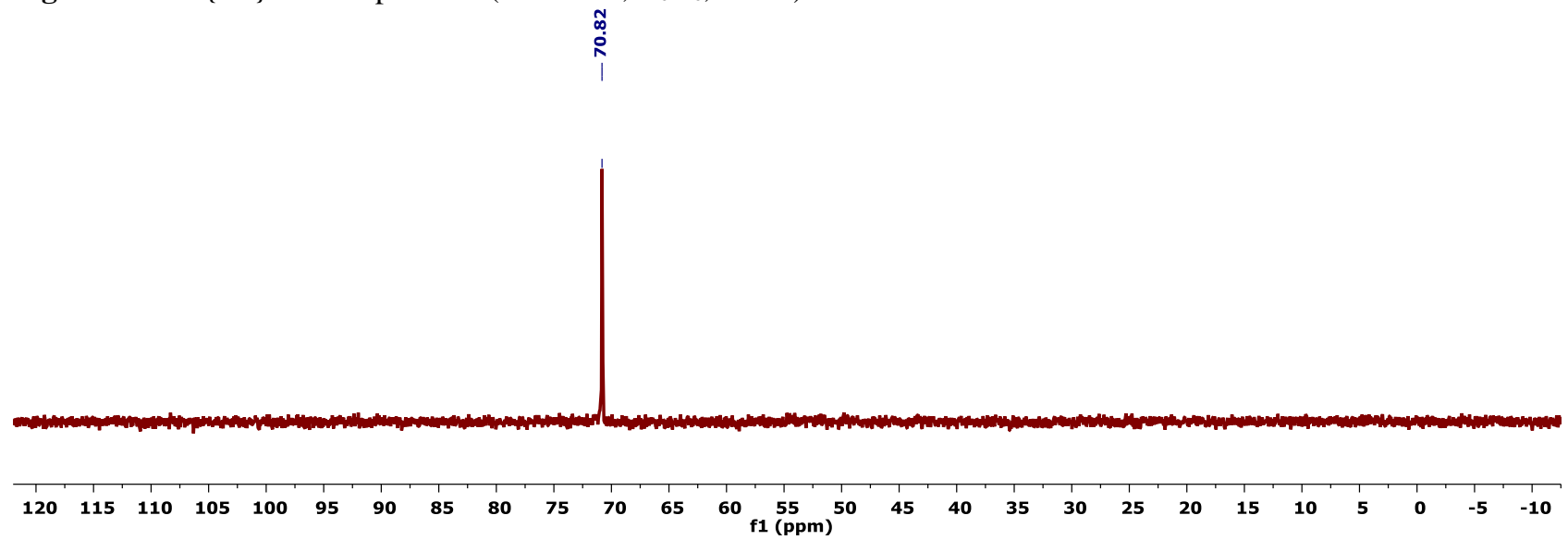

Figure S8. ${ }^{31} \mathrm{P}\left\{{ }^{1} \mathrm{H}\right\}$ NMR Spectrum $\left(162 \mathrm{MHz}, \mathrm{C}_{6} \mathrm{D}_{6}, 23{ }^{\circ} \mathrm{C}\right)$ of $\mathbf{6}$. 


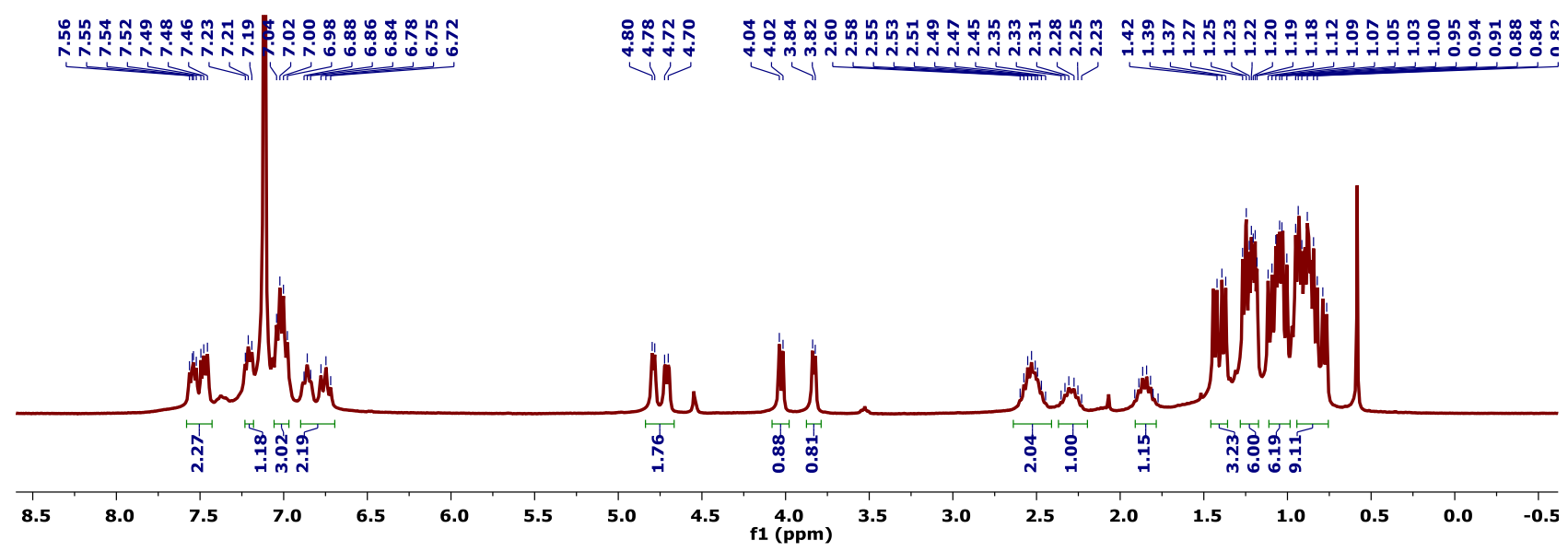

Figure S9. ${ }^{1} \mathrm{H}$ NMR Spectrum $\left(300 \mathrm{MHz}, \mathrm{C}_{6} \mathrm{D}_{6}, 23{ }^{\circ} \mathrm{C}\right)$ of in situ generated 9.

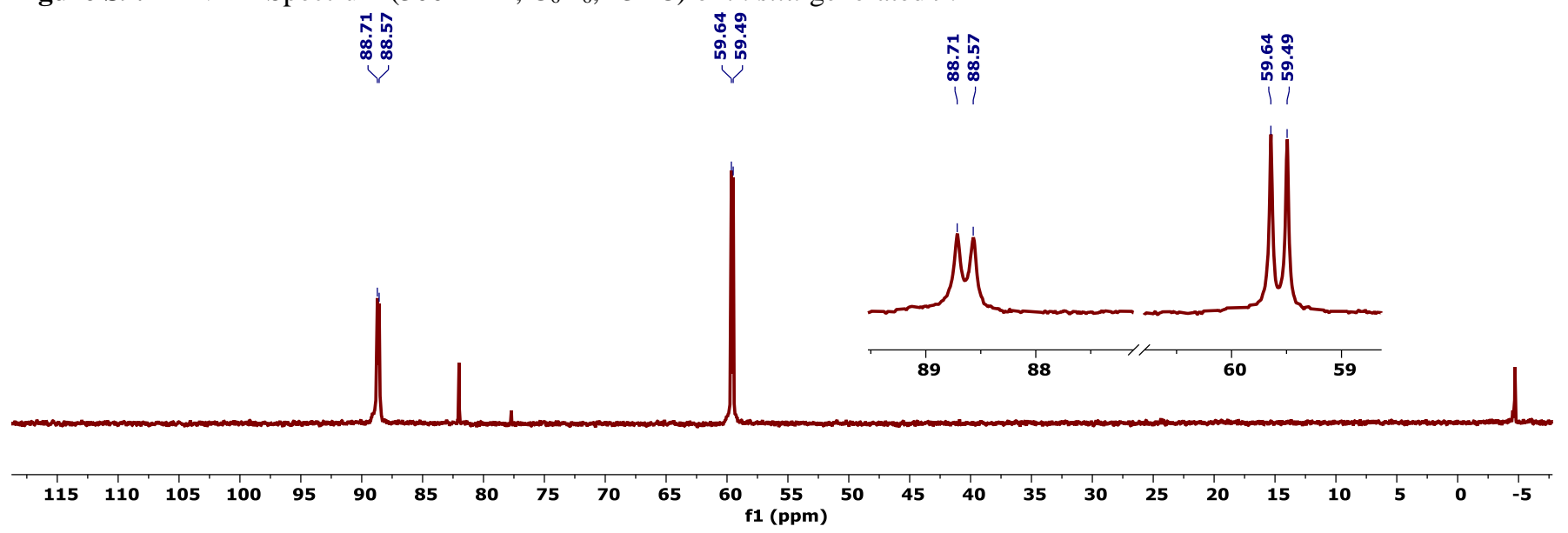

Figure S10. ${ }^{31} \mathrm{P}\left\{{ }^{1} \mathrm{H}\right\}$ NMR Spectrum $\left(121 \mathrm{MHz}, \mathrm{C}_{6} \mathrm{D}_{6}, 23{ }^{\circ} \mathrm{C}\right)$ of of in situ generated 9. 


\section{Silane Coordination Chemistry}

A J. Young style NMR tube was charged with a solution of complex 1 (25 mg, $0.043 \mathrm{mmol}, 1$ equiv.) in $\mathrm{C}_{6} \mathrm{D}_{6}(0.4 \mathrm{~mL})$. To this deep red solution, $\mathrm{PhMeSiH}_{2}(5.9 \mu \mathrm{L}, 0.043 \mathrm{mmol}, 1$ equiv.) was added via microsyringe, resulting in a slight lightening to red/orange. The tube was sealed, and the contents thoroughly mixed via shaking. ${ }^{31} \mathrm{P}$ NMR spectroscopy evidenced $c a .50 \%$ conversion of the starting material to coupling doublets at 74.14 and $68.28 \mathrm{ppm}\left({ }^{2} J_{(\mathrm{P}, \mathrm{P})}=24.7 \mathrm{~Hz}\right)$, assigned to asymmetric silyl hydride complex, 6' (Fig. S11, top). Degassing the reaction vessel via a single freeze-pump-thaw cycle increased the conversion, which was rendered quantitative after a second degassing (Fig. S11).

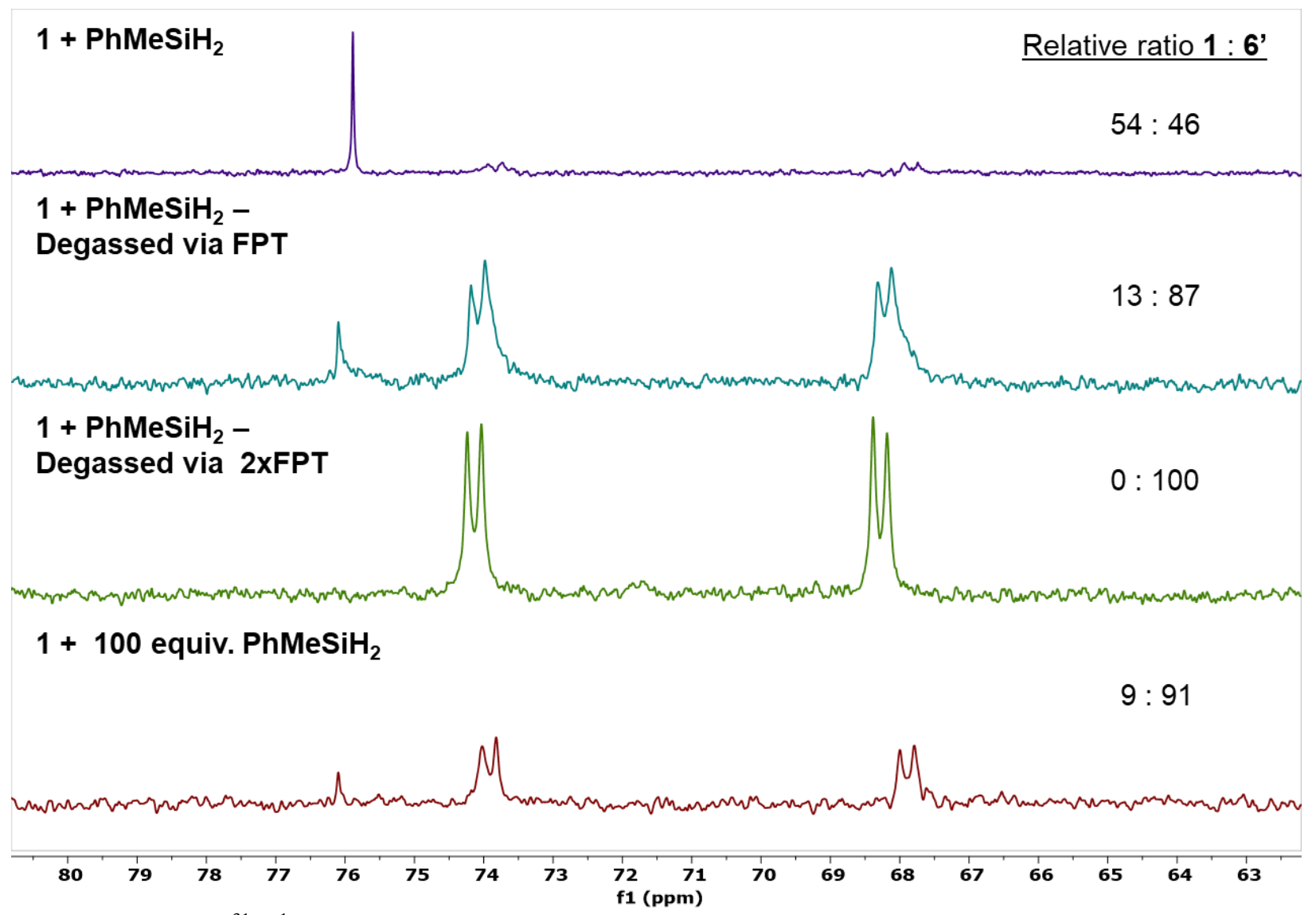

Figure S11. Partial ${ }^{31} \mathrm{P}\left\{{ }^{1} \mathrm{H}\right\}$ NMR spectra $\left(121 \mathrm{~Hz}, 23^{\circ} \mathrm{C}, \mathrm{C}_{6} \mathrm{D}_{6}\right)$ demonstrating the conversion of dinitrogen adduct 1 to phenylmethylsilyl hydride complex $\mathbf{6}^{\prime}$.

While not analytically pure, the salient ${ }^{1} \mathrm{H}$ NMR features for this new asymmetric species corroborate its assignment as a silyl hydride complex (Fig. S12). ${ }^{1} \mathrm{H}\left(300 \mathrm{MHz}, \mathrm{C}_{6} \mathrm{D}_{6}, 23{ }^{\circ} \mathrm{C}\right) \delta: 7.74$ (br s, $2 \mathrm{H}$, aryl- $H$ ), 7.32-7.40 (m, 2H, aryl-H), $7.09(\mathrm{~s}, 2 \mathrm{H}$, aryl- $H), 6.85-7.03(\mathrm{~m}, 7 \mathrm{H}$, aryl-H), $5.72($ br s, $1 \mathrm{H}, \mathrm{Si}-H), 4.67$ (br $\mathrm{s}, 1 \mathrm{H}$, central arene- $H$ ), 4.56 (br s, $1 \mathrm{H}$, central arene- $H), 6.44$ (br s, $1 \mathrm{H}$, central arene- $H), 4.23$ (br s, $1 \mathrm{H}$, central arene- $H$ ), 2.03-2.20 (m, $\left.4 \mathrm{H}, \mathrm{CH}\left(\mathrm{CH}_{3}\right)_{2}\right), 0.88-1.25\left(\mathrm{~m}, 24 \mathrm{H}, \mathrm{CH}\left(\mathrm{CH}_{3}\right)_{2}\right), 0.67$ (br s, 3H, Si-CH3), $-3.36(\mathrm{t}, J=39.1 \mathrm{~Hz}, 1 \mathrm{H}, \mathrm{Mo}-H)$. 


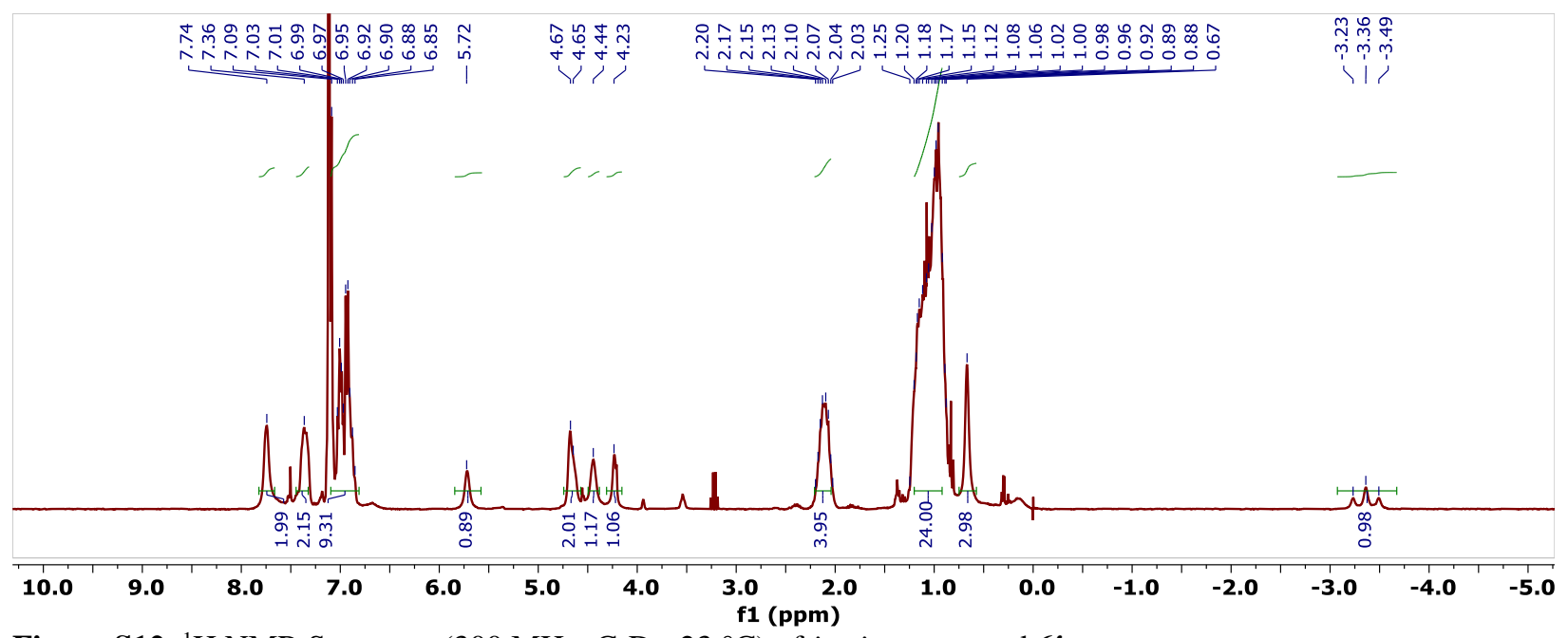

Figure S12. ${ }^{1} \mathrm{H}$ NMR Spectrum $\left(300 \mathrm{MHz}, \mathrm{C}_{6} \mathrm{D}_{6}, 23{ }^{\circ} \mathrm{C}\right)$ of in situ generated $\mathbf{6}^{\prime}$.

Degassing samples prepared with a single equivalent of silane proved more effective at promoting $\mathrm{Si}-\mathrm{H}$ oxidative addition than adding a gross excess of $\mathrm{PhMeSiH}_{2}$ (Fig. S11, bottom). 


\section{$\mathrm{CO}_{2}$ Cleavage Kinetics}

In a representative reaction, a J. Young style NMR tube was charged with a deep red $\mathrm{C}_{6} \mathrm{D}_{6}$ solution $(0.6$ $\mathrm{mL}$ ) of 1 ( $25 \mathrm{mg}, 0.043 \mathrm{mmol}, 1$ equiv.). $\mathrm{PhMeSiH}_{2}(5.9 \mu \mathrm{L}, 0.043 \mathrm{mmol}, 1$ equiv.) was added via microsyringe, leading to a slight lightening to red/orange. The tube was sealed and the contents frozen solid in a $-78{ }^{\circ} \mathrm{C}$ dry ice/acetone slurry. The headspace was evacuated thoroughly via three freeze-pump-thaw cycles. After the third evacuation cycle, the tube was carefully positioned such that only the solution was submerged in the cooling bath and $\mathrm{CO}_{2}(1 \mathrm{~atm}$.) was admitted to the head space. The tube was thawed directly prior to introduction to an NMR probe pre-heated to $70{ }^{\circ} \mathrm{C} .{ }^{1} \mathrm{H}$ NMR spectra were collected at 2 minute intervals and the cleavage of $\mathrm{CO}_{2}$ was monitored via growth of the ${ }^{1} \mathrm{H}$ resonance at $4.59 \mathrm{ppm}$, a diagnostic central arene resonance of monocarbonyl complex $\mathbf{8} .^{3}$

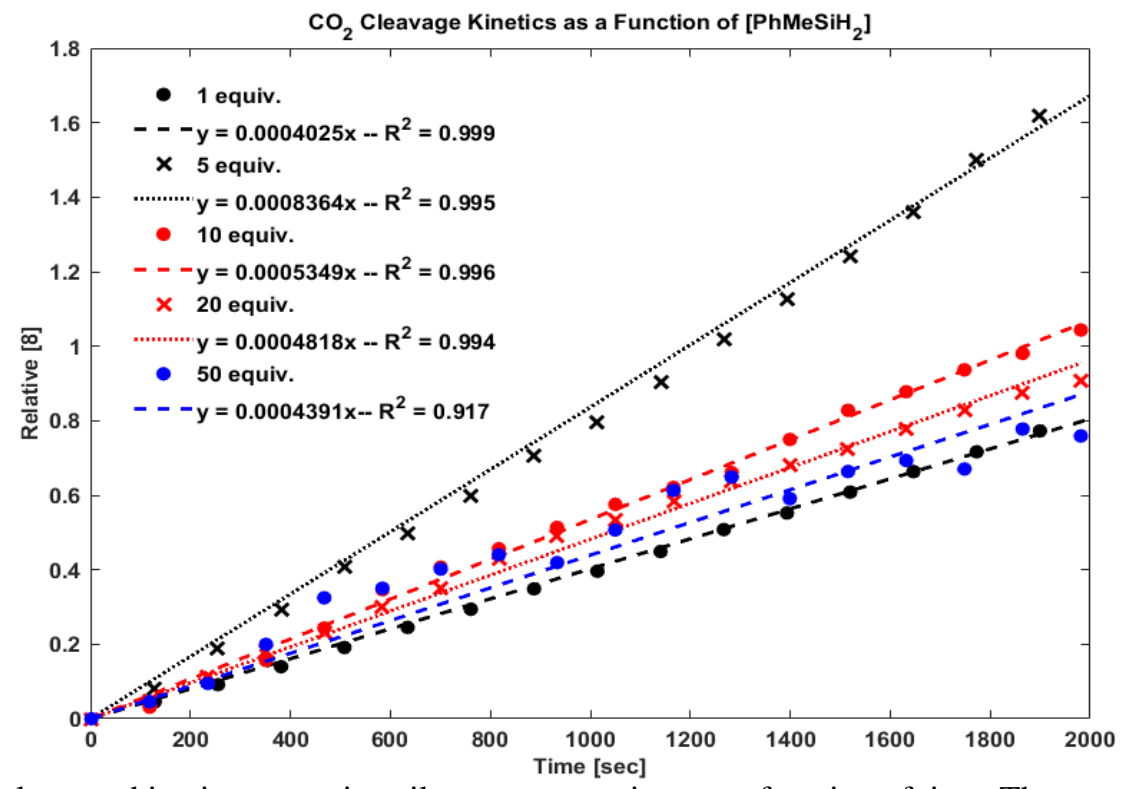

Figure S13. $\mathrm{CO}_{2}$ cleavage kinetics at varying silane concentrations as a function of time. The rate of $\mathrm{CO}_{2}$ reduction increases from $1[\bullet]$ to 5 equiv. $[x]$ of $\mathrm{PhMeSiH}_{2}$ and subsequently decreases at higher silane concentrations-10 $[\bullet], 20[\times]$, and $50[\bullet]$ equiv.

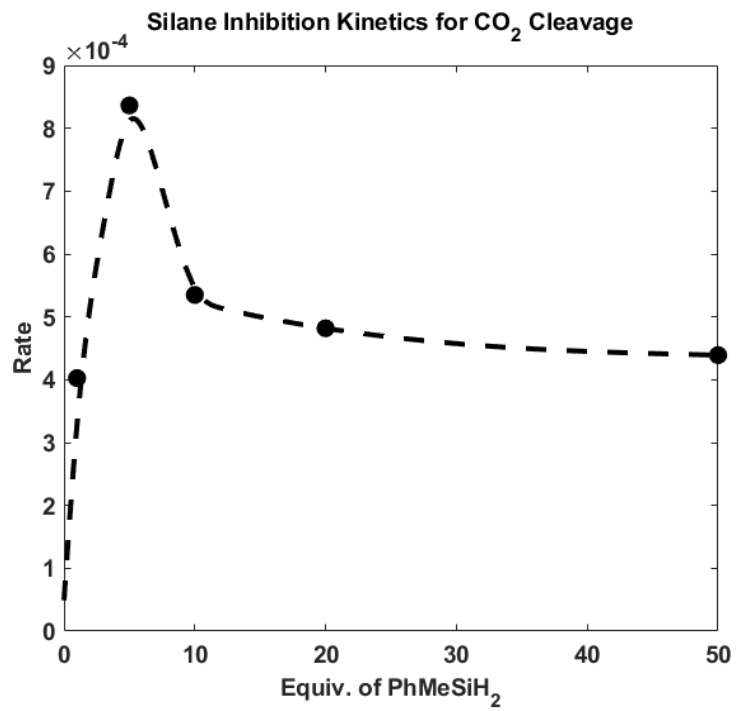

Figure S14. Substrate inhibition kinetics for $\mathrm{CO}_{2}$ cleavage in the presence of $\mathrm{PhMeSiH}_{2}$. 


\section{GC/MS Data for Silanol Identification}

Phenylmethylsilanol was identified as the product of oxygen-atom transfer via the following NMR spectroscopy and gas chromatography/mass spectrometry experiments.

In a representative reaction, a J. Young style NMR tube was charged with a deep red $\mathrm{C}_{6} \mathrm{D}_{6}$ solution $(0.6$ $\mathrm{mL}$ ) of 1 ( $25 \mathrm{mg}, 0.043 \mathrm{mmol}, 1$ equiv.). $\mathrm{PhMeSiH}_{2}(5.9 \mu \mathrm{L}, 0.043 \mathrm{mmol}, 1$ equiv.) was added via microsyringe, leading to a slight lightening to red/orange. ${ }^{1} \mathrm{H}$ and ${ }^{31} \mathrm{P}\left\{{ }^{1} \mathrm{H}\right\}$ NMR spectra at this juncture demonstrated $c a .31 \%$ conversion of $\mathbf{1}$ to $\mathbf{6}^{\prime}$ (Fig. S15, top).

The tube was sealed and the contents frozen solid in a $-78{ }^{\circ} \mathrm{C}$ dry ice/acetone slurry. The headspace was evacuated thoroughly via three freeze-pump-thaw cycles. After the third evacuation cycle, the tube was carefully positioned such that only the solution was submerged in the cooling bath and $\mathrm{CO}_{2}(1 \mathrm{~atm}$.) was admitted to the head space. The tube was thawed and placed in a $70{ }^{\circ} \mathrm{C}$ oil bath for $8 \mathrm{~h}$. At this time, the reaction was analyzed again by multinuclear NMR spectroscopy, showing complete conversion to 8 (Fig. S15, bottom).

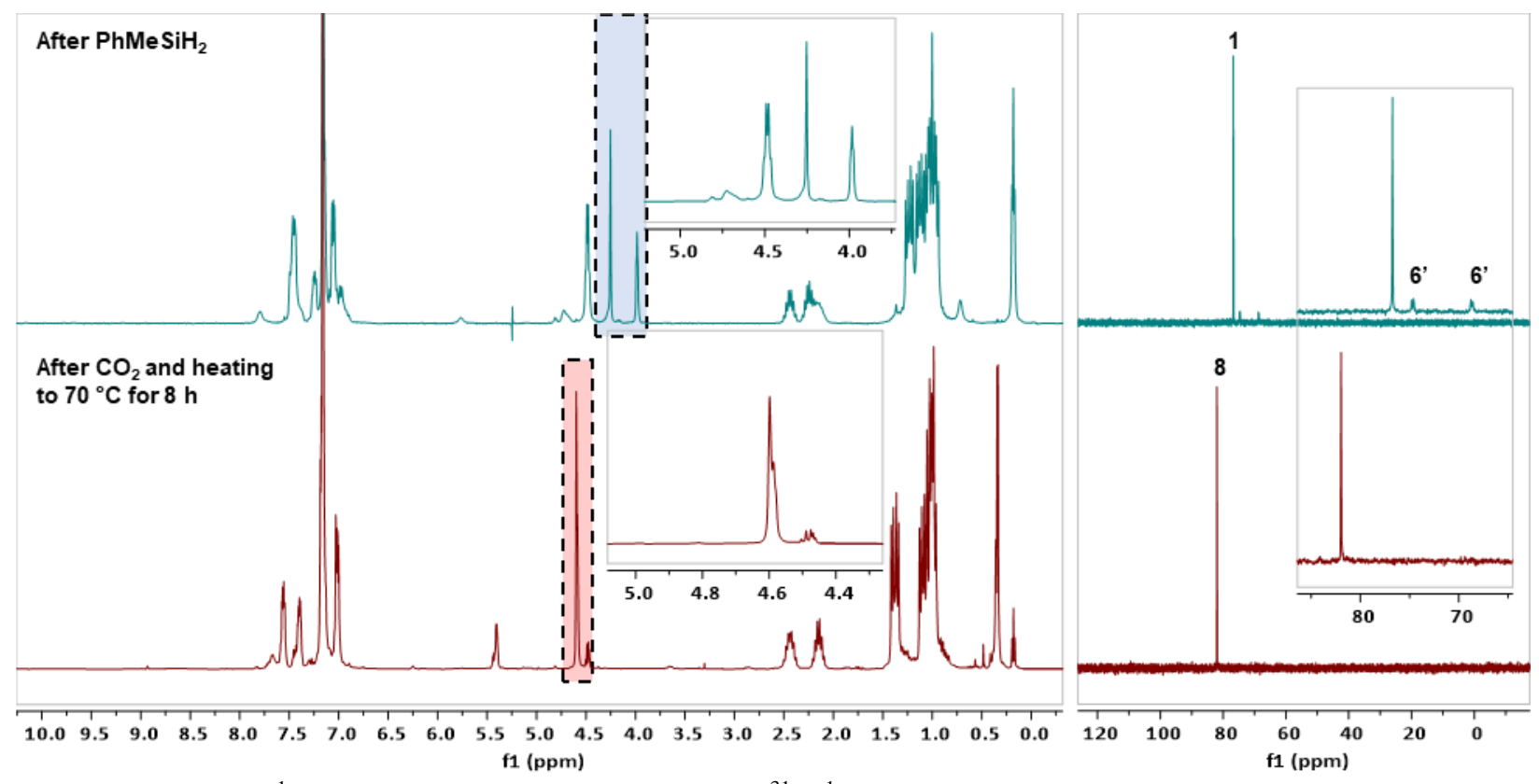

Figure S15. Partial ${ }^{1} \mathrm{H}$ (left; $300 \mathrm{MHz}, 23{ }^{\circ} \mathrm{C}, \mathrm{C}_{6} \mathrm{D}_{6}$ ) and ${ }^{31} \mathrm{P}\left\{{ }^{1} \mathrm{H}\right\}$ (right; $121 \mathrm{MHz}, 23{ }^{\circ} \mathrm{C}, \mathrm{C}_{6} \mathrm{D}_{6}$ ) NMR spectra of a reaction mixture prepared as described above. The shaded regions and enlarged insets highlight the diagnostic central arene resonances of $\mathbf{1}$ (blue) and $\mathbf{8}$ (red), respectively.

In a fume hood, the contents of the tube were filtered through a short silica plug (ca. 1.5" in a 9" Pasteur pipette) into a $20 \mathrm{~mL}$ scintillation vial. The plug was further washed with $1 \mathrm{~mL}$ of DCM (benchtop) and two drops of the combined filtrate were transferred to a $\mathrm{GC}$ vial, diluted with $\mathrm{MeOH}$, and analyzed by GC/MS.

A control reaction was run, following the procedure outlined above, but with the omission of complex $\mathbf{1}$. 


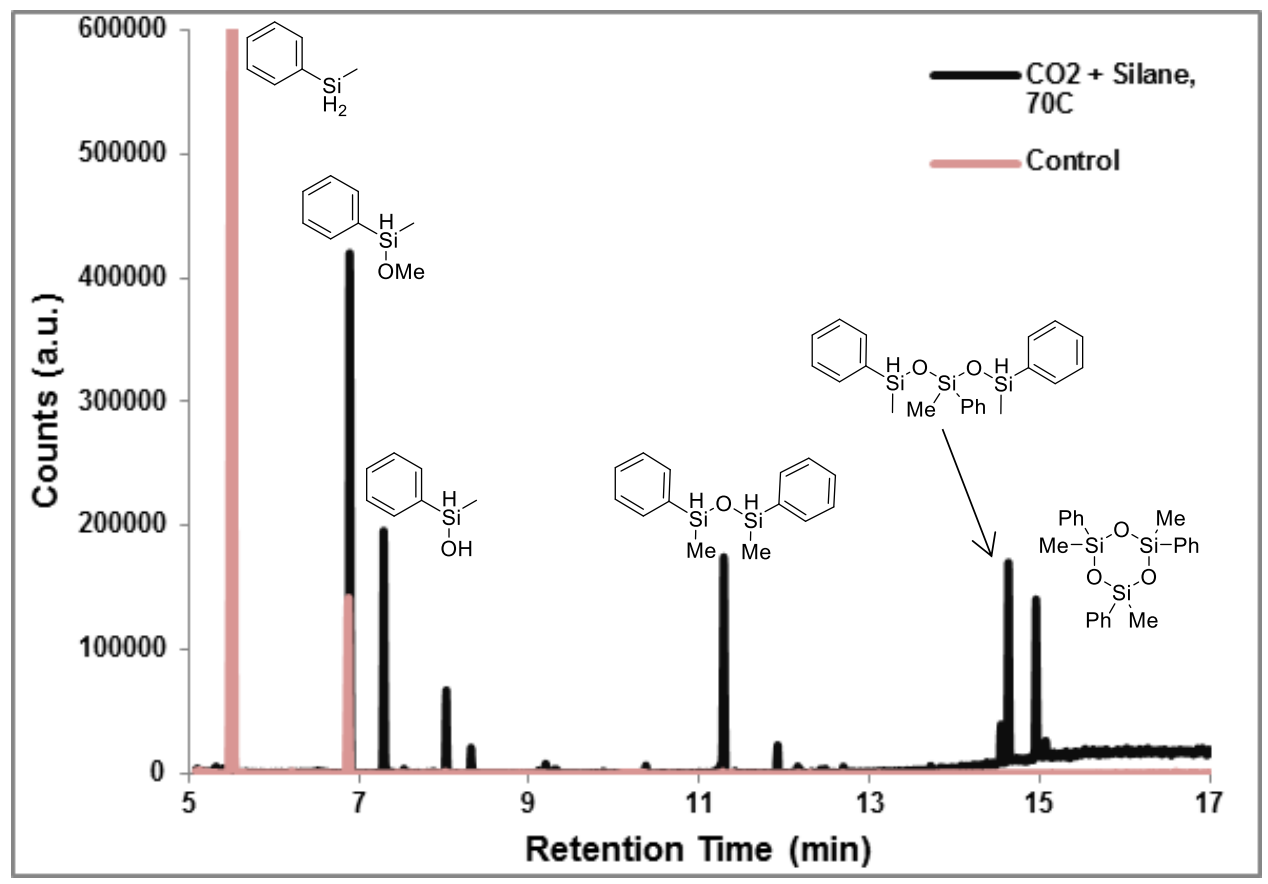

Figure S16. GC trace from a $\mathrm{CO}_{2}$ cleavage reaction mixture demonstrating the formation of silanol, silyl ethers, and polysiloxane (black). The GC trace of a control reaction run in the absence of $\mathbf{1}$ is included for reference (red). 


\section{Standard Procedures for Catalytic Reactions}

Standard procedure for $\mathrm{CO}_{2}$ hydrogenation catalysis:

In the glove box, 1 (14.7 $\mathrm{mg}, 25 \mathrm{mmol}$ ), base (added as a solid or via microsyringe), and additive (added as a solid, only in entry 1 ) were loaded into a Teflon stoppered Schlenk tube charged with a stir bar. THF (5 $\mathrm{mL})$ was added, resulting in a red mixture of $1(5 \mu \mathrm{M})$, base $(0.5 \mathrm{mM})$, and additive $(0.5 \mathrm{mM}$, where applicable). After sealing, the vessel was brought out of the glove box, connected to a Schlenk line, and the reaction solution was degassed via three freeze-pump-thaw cycles. The flask was backfilled with $\mathrm{CO}_{2}(1$ atm.) and then re-frozen in $\mathrm{LN}_{2}$, condensing the $\mathrm{CO}_{2}$. The tube was positioned such that only the solution was submerged in $\mathrm{LN}_{2}$ and $\mathrm{H}_{2}(1 \mathrm{~atm}$.) was admitted. After the gas addition, the reaction solution was allowed to thaw and the Schlenk tube placed in an oil bath pre-heated to $70{ }^{\circ} \mathrm{C}$. Following completion, the reaction was quenched by opening the vessel to the air. The solution was pumped down under reduced pressure, then deuterium oxide ( $c a .3 \mathrm{~mL}$ ) was added to solubilize any formate salts. The insoluble materials were removed by filtration through a glass fiber. DMF was added as an internal standard to the filtrate and the formation of formate salts was quantified by ${ }^{1} \mathrm{H}$ NMR spectroscopy.

For catalytic conditions, refer to Table 1 of the manuscript.

\section{Standard procedure for FA dehydrogenation catalysis:}

In the glove box, $1(1.55 \mathrm{mg}, 0.00265 \mathrm{mmol}, 0.1 \mathrm{~mol} \%)$ in dioxane $(5 \mathrm{~mL})$-prepared as a stock solution and kept frozen when not in use-and additive $(0.0265 \mathrm{mmol}, 10 \mathrm{~mol} \%$ - either added as a solid or via microsyringe) were loaded into $25 \mathrm{~mL}$ Schlenk flask charged with a stir bar. After sealing, the Schlenk flask was brought out of the glove box and connected to Eudiometry setup filled with nitrogen atmosphere. ${ }^{2}$ The Schlenk flask was submerged in an oil bath pre-heated to $80^{\circ} \mathrm{C}$ and stirred for 15 min to reach thermal equilibrium. Formic acid $(0.1 \mathrm{~mL}, 2.65 \mathrm{mmol}, 1$ equiv.) was added quickly via syringe. Following regulation of the pressure, the Eudiometer was opened, and the gas evolution was monitored as a function of time.

For catalytic conditions, refer to Table 2 of the manuscript.

\section{Characteristic Gas Evolution Time-Course}

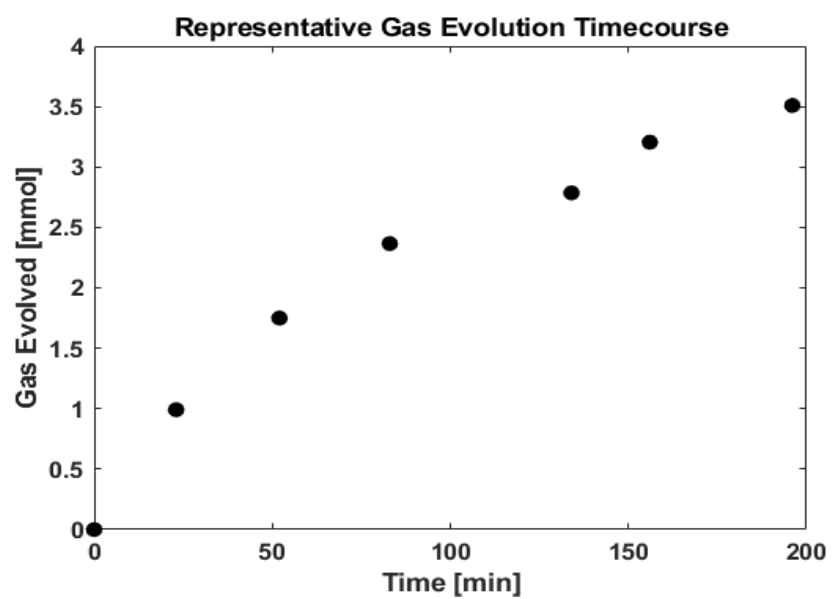

Figure S17. Gas evolution as a function of time for a typical high turnover formic acid dehydrogenation experiment (the data shown corresponds to Table 2, entry 8). In all cases, negligible gas evolution was observed after the reported time/TON. 


\section{Catalyst Decomposition Analysis}

To explore the fate of the catalyst, a formic acid dehydrogenation trial was run under modified standard conditions with a $1 \mathrm{~mol} \%$ loading of dinitrogen adduct $\mathbf{1}$. Removal of volatiles and analysis of the resulting products by multinuclear NMR spectroscopy corroborated formation of a mixture of $\mathbf{8}, \mathbf{P 2}^{\mathbf{O}}$, and free ligand (P2).

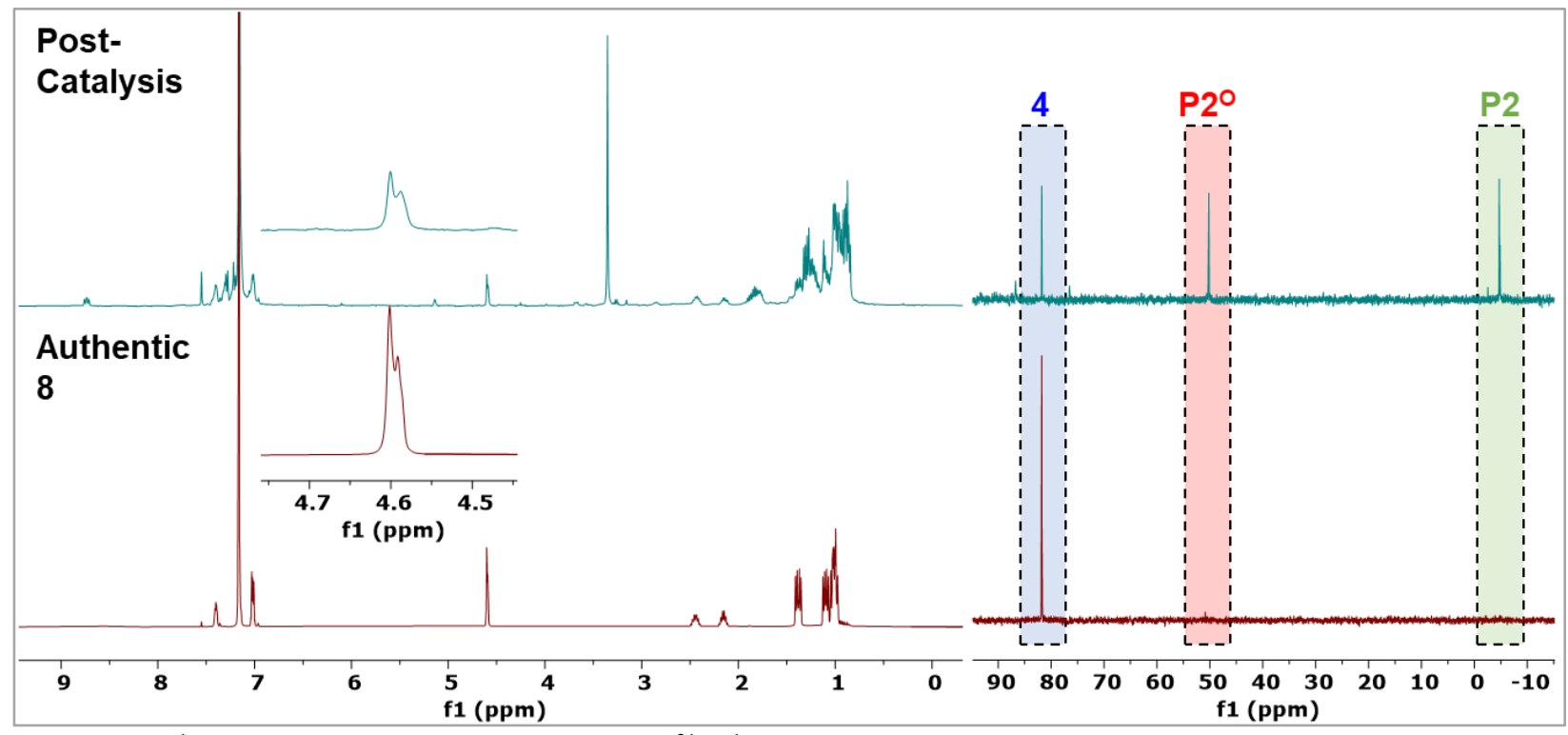

Figure S18. ${ }^{1} \mathrm{H}$ (left- $400 \mathrm{MHz}, 23{ }^{\circ} \mathrm{C}, \mathrm{C}_{6} \mathrm{D}_{6}$ ) and ${ }^{31} \mathrm{P}\left\{{ }^{1} \mathrm{H}\right\}$ (right- $162 \mathrm{MHz}, 23{ }^{\circ} \mathrm{C}, \mathrm{C}_{6} \mathrm{D}_{6}$ ) spectra following catalytic formic acid dehydrogenation (top) in comparison to an authentic sample (bottom) of Mo monocarbonyl complex $\mathbf{8}$. The insets highlight the central arene protons of 8 and the shaded boxes designate speciation in the ${ }^{31} \mathrm{P}\left\{{ }^{1} \mathrm{H}\right\} \mathrm{NMR}$ spectrum. 


\section{Stoichiometric Reactions Targeting Catalytically Relevant Reaction Steps}

\section{Stoichiometric Addition of Formic Acid}

To investigate the stoichiometric reactivity between dinitrogen adduct $\mathbf{1}$ and formic acid, a J. Young style NMR tube was charged with a solution of $1\left(25 \mathrm{mg}, 0.043 \mathrm{mmol}, 1\right.$ equiv.) in $\mathrm{C}_{6} \mathrm{D}_{6}(0.5 \mathrm{~mL})$. Formic acid ( $8.1 \mu \mathrm{L}, 0.215 \mathrm{mmol}, 5$ equiv.) was added via microsyringe. The J. Young tube was then sealed, mixed, and the contents analyzed by multinuclear NMR spectroscopy. The ${ }^{1} \mathrm{H}$ NMR spectrum showed free formic acid and the ${ }^{31} \mathrm{P}\left\{{ }^{1} \mathrm{H}\right\}$ NMR spectrum evidenced two primary diamagnetic molybdenum complexes (Fig. $\mathrm{S} 19$, top). Upon heating the reaction solution to $70^{\circ} \mathrm{C}$ for one hour, the formic acid was consumed, hydrogen was generated, and the predominant metal complex in solution was formate hydride complex 4 (Fig. S19, middle).

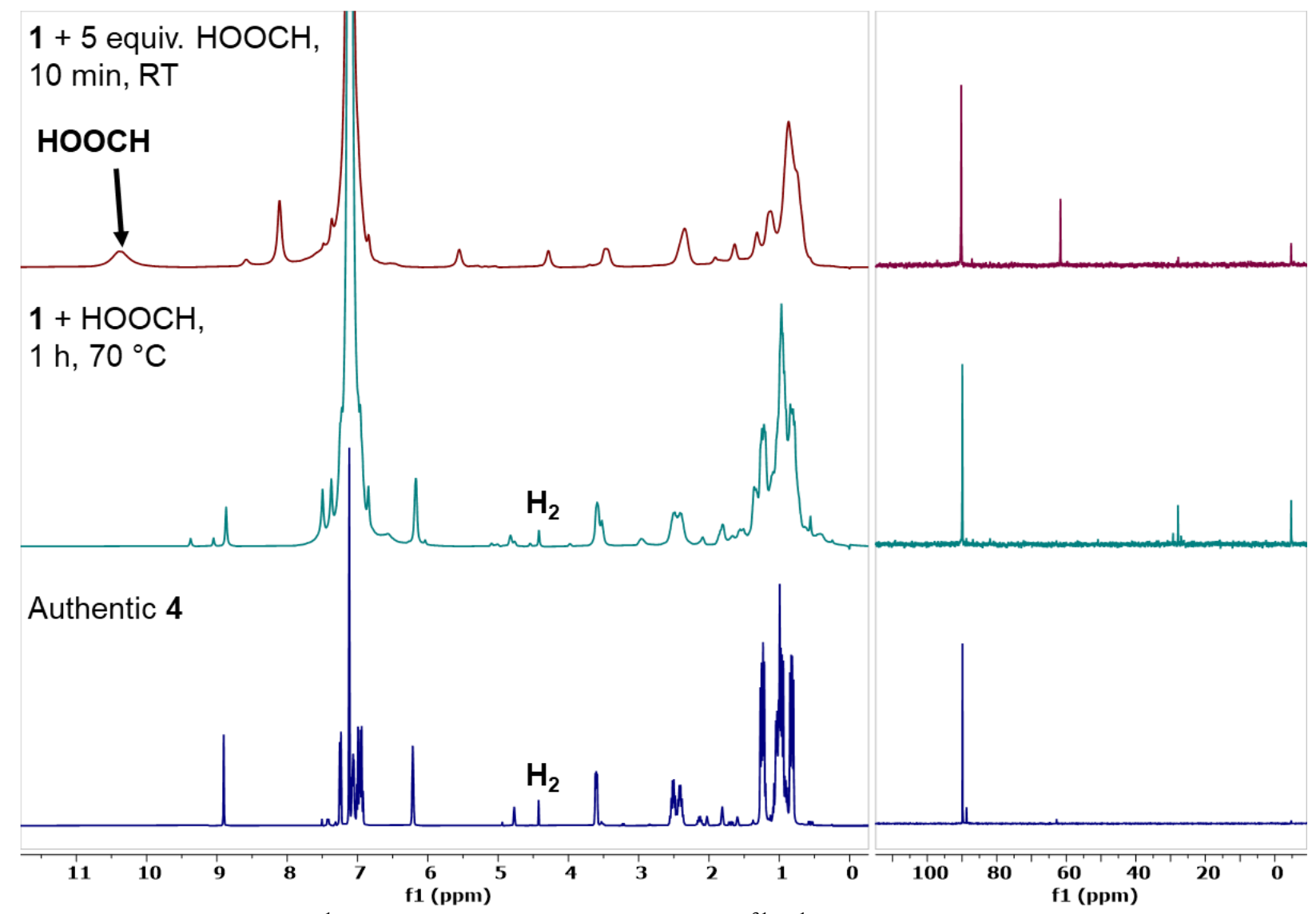

Figure S19. Stacked partial ${ }^{1} \mathrm{H}$ (left-300 MHz, $25{ }^{\circ} \mathrm{C}, \mathrm{C}_{6} \mathrm{D}_{6}$ ) and ${ }^{31} \mathrm{P}\left\{{ }^{1} \mathrm{H}\right\}$ (right-121 $\mathrm{MHz}, 25{ }^{\circ} \mathrm{C}, \mathrm{C}_{6} \mathrm{D}_{6}$ ) spectra monitoring conversion of $\mathbf{1}$ to $\mathbf{4}$ in the presence of formic acid. The bottom spectra show independently prepared $\mathbf{4}$ for comparison.

\section{Thermal Decomposition of 4}

A sample of 4 in a J. Young style NMR tube was prepared as follows: 1 ( $25 \mathrm{mg}, 0.043 \mathrm{mmol}, 1$ equiv.) was dissolved in $0.5 \mathrm{~mL}$ of $\mathrm{C}_{6} \mathrm{D}_{6}$. The tube was sealed, and the contents frozen solid in liquid nitrogen. The headspace was evacuated, the contents of the tube thawed, and $\mathrm{CO}_{2}(1 \mathrm{~atm}$.) was admitted at room temperature, leading to a lightening of the deep red solution to red orange. The tube was re-frozen in liquid nitrogen, simultaneously condensing the $\mathrm{CO}_{2}$. While frozen, the tube was opened to $\mathrm{H}_{2}(1 \mathrm{~atm}$.). Following this second gas addition, the tube was carefully thawed and mixed thoroughly via inversion. ${ }^{31} \mathrm{P}\left\{{ }^{1} \mathrm{H}\right\} \mathrm{NMR}$ spectroscopy demonstrated $c a .91 \%$ conversion to formate hydride 4 . 
Mixing the reaction via inversion of the J. Young tube for $3 \mathrm{~h}$ led to little change in the reaction speciation; however, after heating to $70{ }^{\circ} \mathrm{C}$ for $1 \mathrm{~h}, 4$ converted to dihydride 2 (40\%), $\mathrm{CO}_{2}$ adduct 3 (19\%), and dinitrogen complex $1(23 \%)$.

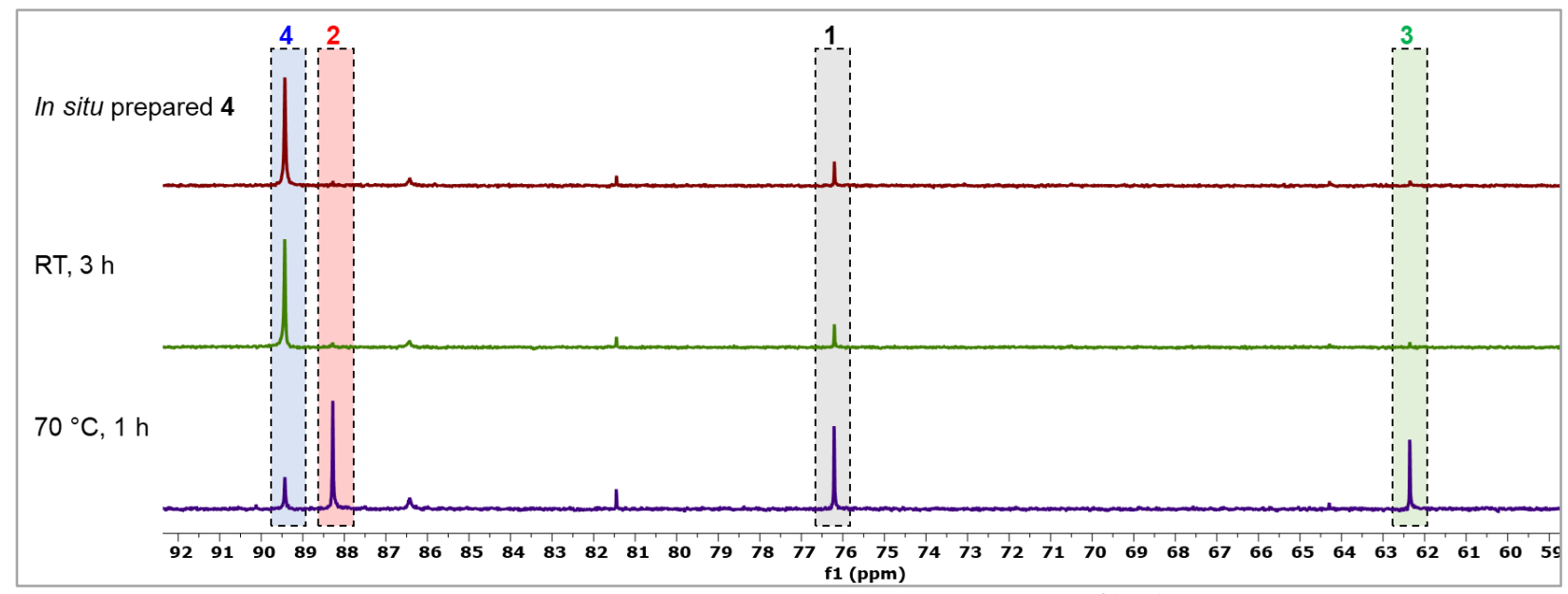

Figure S20. Tracking thermal dehydrogenation of formate hydride complex 4 via ${ }^{31} \mathrm{P}\left\{{ }^{1} \mathrm{H}\right\}$ NMR spectroscopy (121 $\left.\mathrm{MHz}, 25^{\circ} \mathrm{C}, \mathrm{C}_{6} \mathrm{D}_{6}\right)$. An in situ prepared sample of $\mathbf{4}(91 \%)$ shows little conversion at room temperature (middle) but coverts to $\mathbf{1}-\mathbf{3}$ when heated to $70^{\circ} \mathrm{C}$ for $1 \mathrm{~h}$ (bottom).

\section{Stoichiometric Reactions with Lewis Acids and Base}

Given that the following reactions were run at room temperature, they employed isolated 4 (prepared via the procedure described on page $\mathrm{S} 3$ ) under an $\mathrm{N}_{2}$ atmosphere.

In a typical reaction, a J. Young style NMR tube was charged with a solution of 4 ( $20 \mathrm{mg}, 0.033 \mathrm{mmol}, 1$ equiv.) in THF ( $0.6 \mathrm{~mL})$. To this same tube, DBU ( $49.4 \mu \mathrm{L}, 0.330 \mathrm{mmol}, 10$ equiv.), LiOTf (52 $\mathrm{mg}, 0.330$ mmol, 10 equiv.) or both were added. The tube was sealed, at the content mixed via inversion for $8 \mathrm{~h}$.

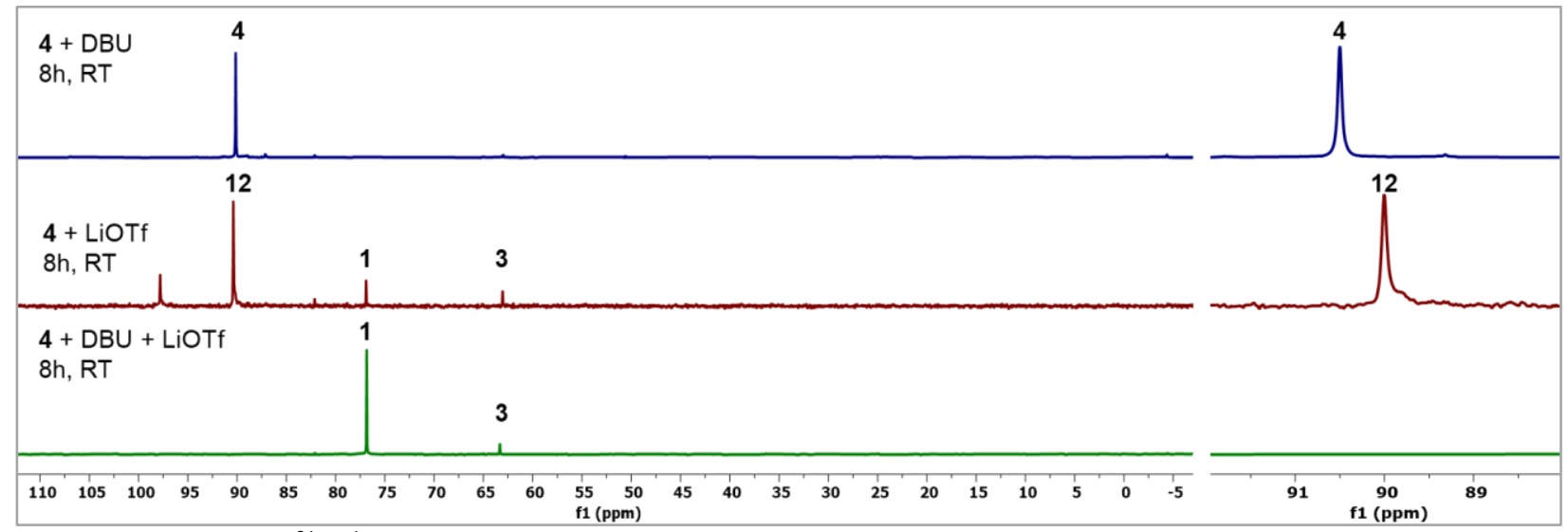

Figure S21. Stacked ${ }^{31} \mathrm{P}\left\{{ }^{1} \mathrm{H}\right\}$ NMR spectra $\left(121 \mathrm{MHz}, 23{ }^{\circ} \mathrm{C}\right.$, THF) of reactions of 4 with DBU (top), LiOTf (middle), and both (bottom). The enlargement to the right highlights the closely spaced but resolved resonances of 4 and hydride cation 12 .

Note: The conversion to 1 observed in the reaction of $\mathbf{4}$ with 10 equiv. of LiOTf could be attributed to minor dehydrogenation under $\mathrm{N}_{2}$ as trace amounts of $\mathbf{2}$ and $\mathbf{3}$ were likewise present in the reaction mixture. 


\section{Independent Synthesis of Hydride Cation 12}

A J. Young style NMR tube was charged with 1 (25 mg, $0.043 \mathrm{mmol}, 1$ equiv.), LutHOTf (11 mg, 0.043 $\mathrm{mg}, 1$ equiv.), and $\mathrm{C}_{6} \mathrm{D}_{6}(0.6 \mathrm{~mL})$. The heterogeneous mixture was heated to $70{ }^{\circ} \mathrm{C}$ for $2 \mathrm{~h}$. Analysis by multinuclear NMR spectroscopy identified a new species, 12, assigned as a hydride cation with the following diagnostic resonances: ${ }^{1} \mathrm{H}\left(300 \mathrm{MHz}, 23{ }^{\circ} \mathrm{C}, \mathrm{C}_{6} \mathrm{D}_{6}\right) \delta: 7.22(\mathrm{~d}, J=7.1 \mathrm{~Hz}, 2 \mathrm{H}$, aryl-H), 7.12 (dd, $J=7.2 \& 5.4 \mathrm{~Hz}, 2 \mathrm{H}$, aryl- $H), 7.02(\mathrm{dd}, J=7.4 \& 6.9 \mathrm{~Hz}, 4 \mathrm{H}$, aryl- $H), 2.39-2.50\left(\mathrm{~m}, 4 \mathrm{H}, \mathrm{CH}\left(\mathrm{CH}_{3}\right)_{2}\right), 2.31$ $(\mathrm{t}, J=86.1 \mathrm{~Hz}, 1 \mathrm{H}, \mathrm{Mo}-H), 1.15\left(\mathrm{dd}, J=16.0 \& 7.0 \mathrm{~Hz}, 12 \mathrm{H}, \mathrm{CH}\left(\mathrm{CH}_{3}\right)_{2}\right), 1.02(\mathrm{dd}, J=14.5 \& 7.2 \mathrm{~Hz}$, $\left.12 \mathrm{H}, \mathrm{CH}\left(\mathrm{CH}_{3}\right)_{2}\right)$. A very broad resonance centered at $4.6 \mathrm{ppm}, \Delta f_{\text {FWHM }} \mathrm{ca}$. $600 \mathrm{~Hz}$, is attributed to the central arene protons. ${ }^{31} \mathrm{P}\left\{{ }^{1} \mathrm{H}\right\}\left(121 \mathrm{MHz}, 23{ }^{\circ} \mathrm{C}, \mathrm{C}_{6} \mathrm{D}_{6}\right) \delta$ : 89.33. ${ }^{31} \mathrm{P}$ spectrum corroborated the ${ }^{2} J(\mathrm{P}, \mathrm{H})$ scalar coupling between the hydride ligand and phosphine donors.

Removal of volatiles from a sample prepared as described above followed by addition of $\mathrm{CD}_{3} \mathrm{CN}$ results in formation of previously reported hydride acetonitrile cation 13 (Fig. S22, bottom), ${ }^{2}$ further corroborating the proposed assignment.

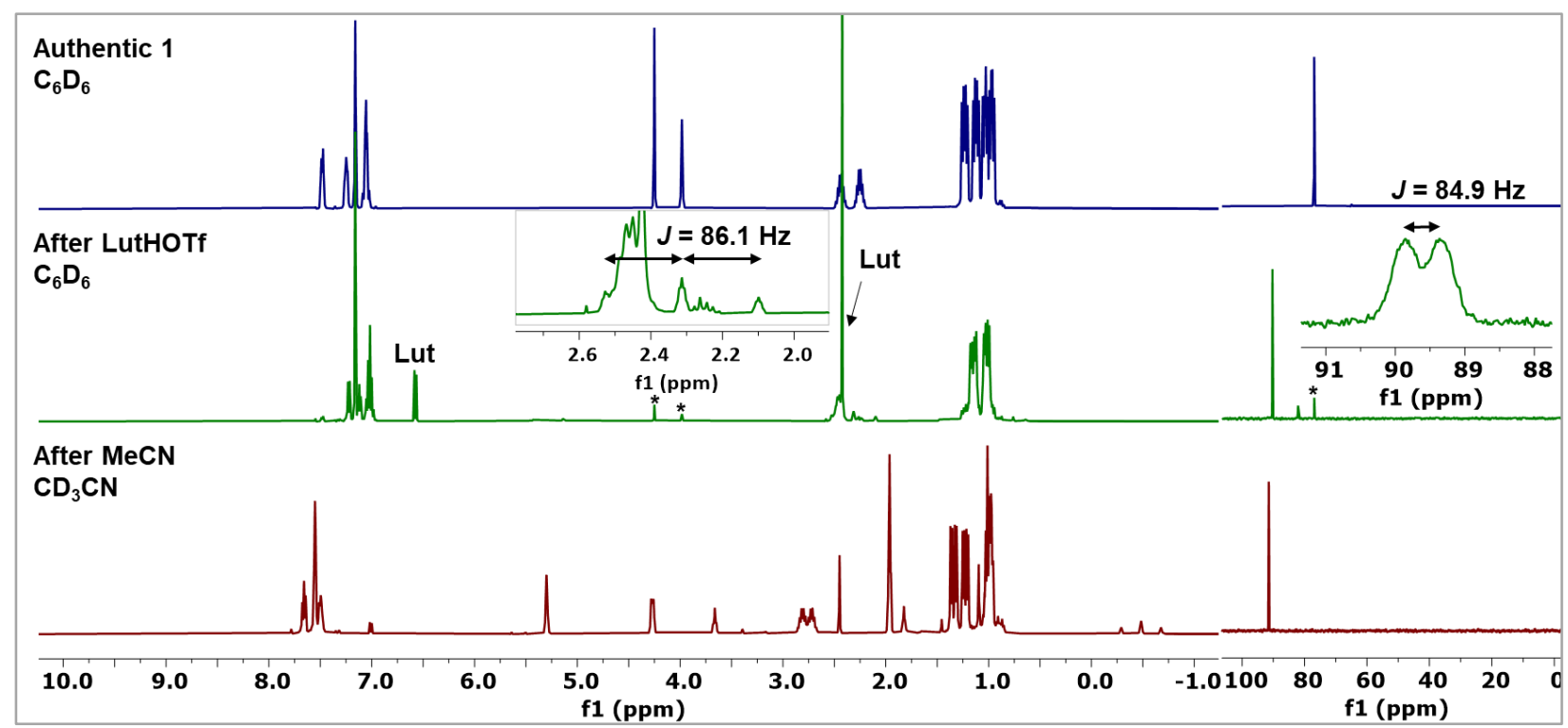

Figure S22. Stacked ${ }^{1} \mathrm{H}$ (left-400 MHz, $\left.23{ }^{\circ} \mathrm{C}, \mathrm{C}_{6} \mathrm{D}_{6}\right)$ and ${ }^{31} \mathrm{P}\left\{{ }^{1} \mathrm{H}\right\}$ (right-162 MHz, $23{ }^{\circ} \mathrm{C}, \mathrm{C}_{6} \mathrm{D}_{6}$ ) NMR spectra of in situ prepared hydride cation 12 and subsequent conversion to reported acetonitrile adduct, 13. The insets shows an enlargement of the hydride resonance at $2.31 \mathrm{ppm}\left({ }^{2} J(\mathrm{H}, \mathrm{P})=86.1 \mathrm{~Hz}\right)$ and the corresponding ${ }^{31} \mathrm{P}$ NMR signal showing appropriate splitting and scalar coupling. Spectra of the same sample in $\mathrm{CD}_{3} \mathrm{CN}$ (bottom) match previously reported 13. Asterisks designate a minor starting material (1) impurity that is insoluble in $\mathrm{MeCN}$.

\section{Protonation Attempts of Formate Hydride 4 and Carboxylate Hydride 5}

A sample of 4 was prepared as described above and $20.0 \mathrm{mg}(0.033 \mathrm{mmol})$ was charged in a J.Young style NMR tube. This tube was sealed, the contents degassed, and $\mathrm{C}_{6} \mathrm{D}_{6}(0.5 \mathrm{~mL})$ admitted via vacuum transfer. ${ }^{1} \mathrm{H}$ and ${ }^{31} \mathrm{P}\left\{{ }^{1} \mathrm{H}\right\}$ NMR spectroscopy showed a mixture comprised predominatnly of $\mathbf{4}$, but with impurities of dinitrogen adduct $\mathbf{1}$ and carbon dioxide adduct $\mathbf{3}$ (Fig. S23, top).

A second J. Yound style NMR tube was charged with complex 4 (24.0 mg, $0.040 \mathrm{mmol}, 1$ equiv.) from the same batch of starting material as the example above. Solid LutHOTf (10.1 mg, $0.040 \mathrm{mmol}, 1$ equiv.) was added to the same tube which was subsequently sealed and degassed. $\mathrm{C}_{6} \mathrm{D}_{6}(0.5 \mathrm{~mL})$ was vacuum transferred into this tube which was sealed, mixed, and analyzed by multinuclear NMR spectroscopy, demonstrating a mixture comprised primarily of hydride cation 12. To confirm the formation of $\mathbf{1 2}$, the 
volatiles were removed under reduced pressure and $\mathrm{CD}_{3} \mathrm{CN}(0.5 \mathrm{~mL})$ was added to the tube via vacuum transfer. ${ }^{1} \mathrm{H}$ and ${ }^{31} \mathrm{P}\left\{{ }^{1} \mathrm{H}\right\}$ NMR spectroscopy demonstrated $\mathbf{1 3}$ as the predominent product (Fig. SX, bottom).

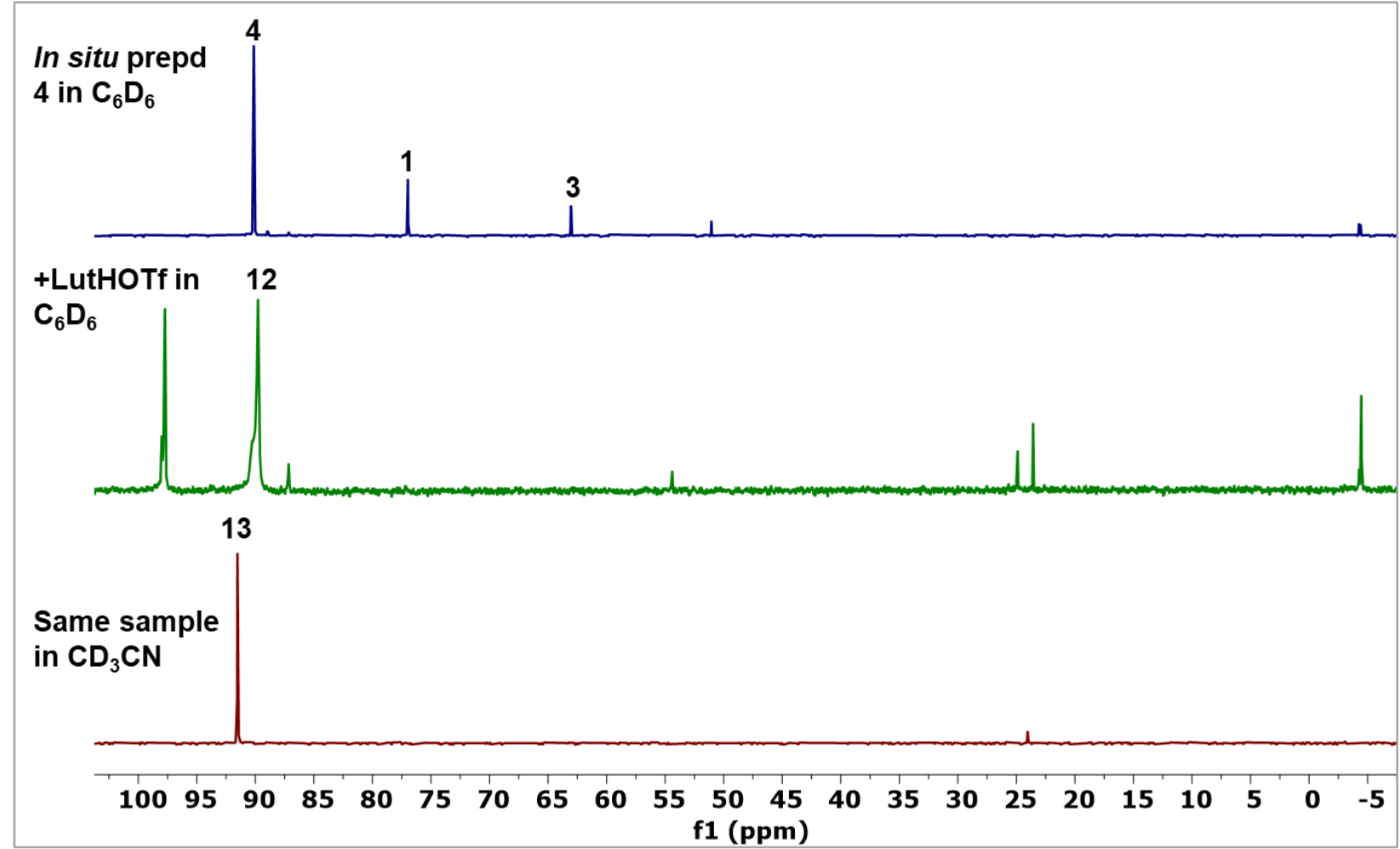

Figure S23. Stacked ${ }^{31} \mathrm{P}\left\{{ }^{1} \mathrm{H}\right\}$ NMR spectra $\left(162 \mathrm{MHz}, 23{ }^{\circ} \mathrm{C}, \mathrm{C}_{6} \mathrm{D}_{6}\right.$ (top and middle) \& $\mathrm{CD}_{3} \mathrm{CN}$ (bottom)) monitoring the protonation of formate hydride complex 4 with LutHOTf. Addition of acid results in a mixture comprised of unidentified species and hydride cation 12. Removal of reaction volatiles and dissolution in $\mathrm{CD}_{3} \mathrm{CN}$ demonstrated clean formation of $\mathbf{1 3}$.

These results suggest the successful protonation of complex $\mathbf{4}$ to afford $\mathbf{1 2}$. Whereas there are equilibrium processes (namely de-insertion from 4 to regerate 1, 2 and 3-all of which can react with acid to yield 12) that may be at play, these are slow on the timescale of the protonation. The experimental results are not inconsistent with the proposed reactivity via formate cation $\mathbf{1 4}$, but they likewise fail to provide direct support for this pathway. As such, protonation of complex $\mathbf{5}$ (a surrogate of $\mathbf{4}$ ) was explored.

A J. Young style NMR tube was charged with solid 5 (26.1 mg, 0.035 mmol, 1 equiv.), LutHOTf (9.1 mg, $0.035 \mathrm{mmol}, 1$ equiv.), and $\mathrm{C}_{6} \mathrm{D}_{6}(0.5 \mathrm{~mL})$. The tube was sealed and the contents mixed via rapid inversion. ${ }^{1} \mathrm{H}$ and ${ }^{31} \mathrm{P}\left\{{ }^{1} \mathrm{H}\right\}$ NMR spectra evidenced conversion to hydride cation 12 (Fig. S24, middle), which was further confirmed via removal of the reaction volatiles and addition of $\mathrm{CD}_{3} \mathrm{CN}$ (Fig. S24, bottom). Free ${ }^{t} \mathrm{BuC}_{6} \mathrm{H}_{4} \mathrm{C}(\mathrm{O}) \mathrm{OH}$ was likewise formed and the relative integration was consistent with exclusive pronolysis of the carboxylate. 


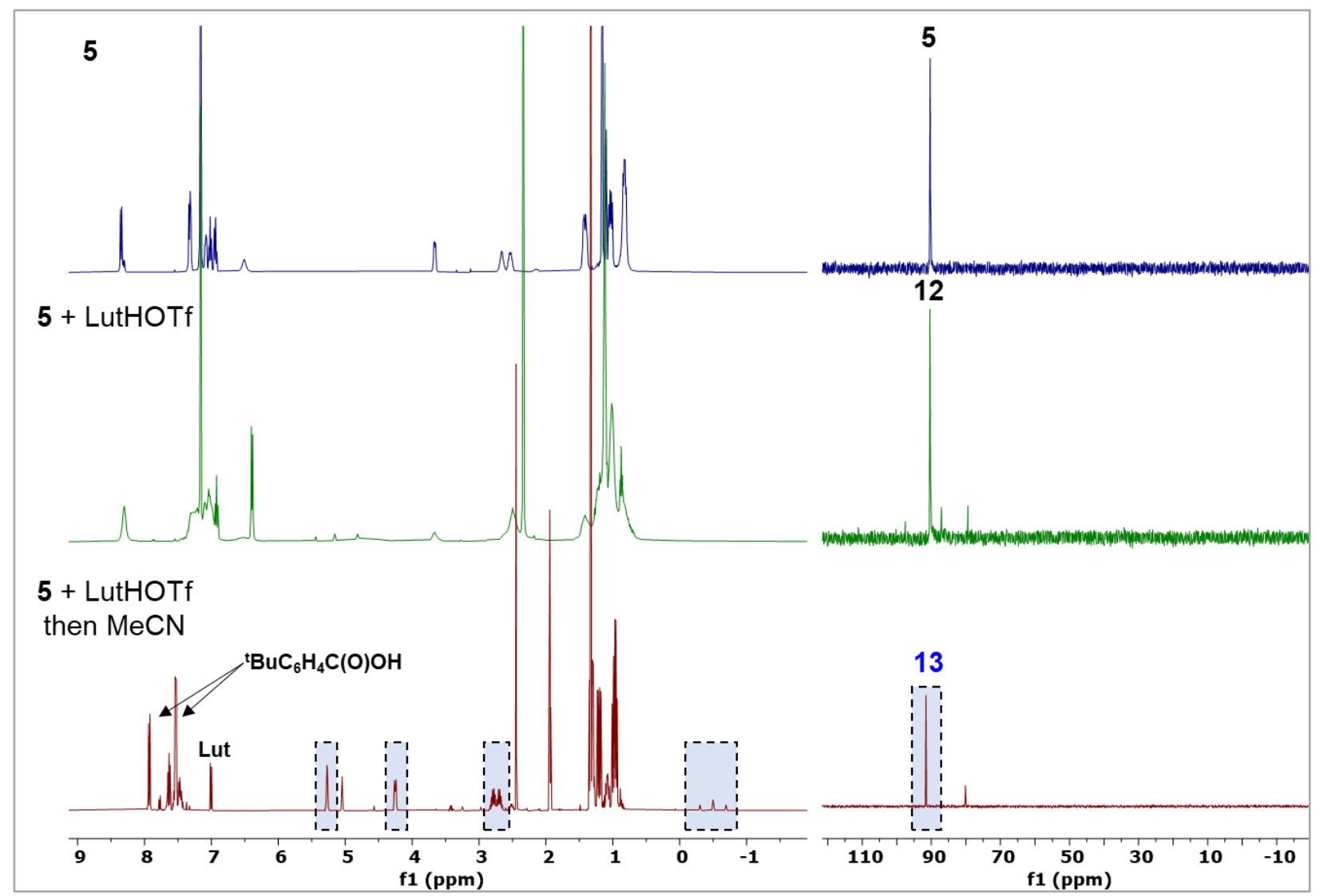

Figure S24. Stacked ${ }^{1} \mathrm{H}$ (left-400 $\mathrm{MHz}, 23{ }^{\circ} \mathrm{C}, \mathrm{C}_{6} \mathrm{D}_{6}$ (top and middle) \& $\mathrm{CD}_{3} \mathrm{CN}$ (bottom)) and ${ }^{31} \mathrm{P}\left\{{ }^{1} \mathrm{H}\right\}$ (right-162 $\mathrm{MHz}, 23{ }^{\circ} \mathrm{C}, \mathrm{C}_{6} \mathrm{D}_{6}$ (top and middle) \& $\mathrm{CD}_{3} \mathrm{CN}$ (bottom)) NMR spectra monitoring the protonation of carboxylate hydride complex 5 with LutHOTf. Addition of acid results predominatnly in formation of hydride cation $\mathbf{1 2}$. Removal of reaction volatiles and dissolution in $\mathrm{CD}_{3} \mathrm{CN}$ demonstrated formation of $\mathbf{1 3}$, the diagnostic resonances of which are highlighted in light blue.

Protonolysis of the formate ligand of $\mathbf{4}$, in an analogous fashion to the reactivity established above, would afford hydride cation 12 without release of $\mathrm{H}_{2}$ or $\mathrm{CO}_{2}$. Addition of excess carboxylic acid to complex 5 showed no reaction under catalytic conditions. These results are consistent with the reactivity of $p$ ${ }^{\mathrm{t}} \mathrm{BuC}_{6} \mathrm{H}_{4} \mathrm{C}(\mathrm{O}) \mathrm{OH}$ differing from that of $\mathrm{HC}(\mathrm{O}) \mathrm{OH}$, with the latter being both more acidic and being capable of additional decarboxylation chemistries. Taken together, these results are neither indicative of nor inconsistent with the mechanism proposed in the "fast" cycle of Scheme 5.

\section{Carboxylate Addition to Hydride Cation 12}

To support the proposed conversion of $\mathbf{1 2}$ to 4 , addition of $p$ - ${ }^{\mathrm{t}} \mathrm{BuC}_{6} \mathrm{H}_{4} \mathrm{C}(\mathrm{O}) \mathrm{ONa}$ to 12 was investigated in an effort to generate carboxylate hydride $\mathbf{5}$.

Hydride cation 12 was synthesized in situ in a J. Young style NMR tube according to the procedure outlined above. This tube was opened in a dinitrogen atmosphere glovebox and ${ }^{\mathrm{t}} \mathrm{BuC} \mathrm{C}_{6} \mathrm{H}_{4} \mathrm{C}(\mathrm{O}) \mathrm{ONa}(8.9 \mathrm{mg}, 0.044$ mmol, 1 equiv.) was added as a solid. The tube was resealed and the contents analyzed by both ${ }^{1} \mathrm{H}$ and ${ }^{31} \mathrm{P}\left\{{ }^{1} \mathrm{H}\right\}$ NMR spectroscopy. The reaction was then heated to $70{ }^{\circ} \mathrm{C}$ and conversion of the starting material monitored over time (Fig. S25). 


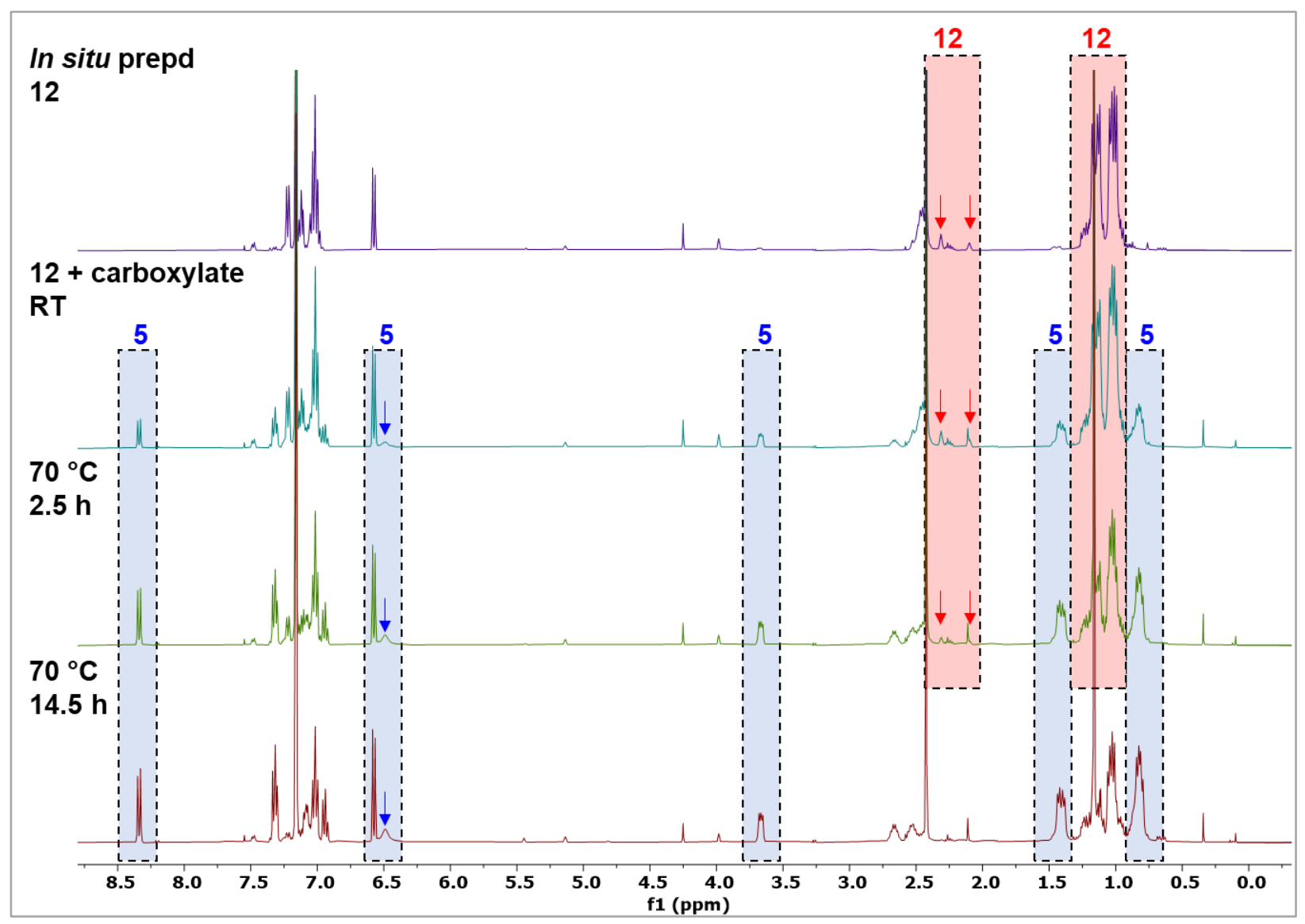

Figure S25. Stacked ${ }^{1} \mathrm{H}\left(400 \mathrm{MHz}, 23{ }^{\circ} \mathrm{C}, \mathrm{C}_{6} \mathrm{D}_{6}\right)$ NMR spectra evidencing the formation of 5 from the reaction of sodium carboxylate with in situ prepared $\mathbf{1 2}$. 


\section{Refinement Details}

CCDC deposition numbers 2091815 - 2091817 contain the supplementary crystallographic data for this paper. These data can be obtained free of charge from The Cambridge Crystallographic Data Centre via www.ccdc.cam.ac.uk/data_request/cif.

Refinement Details - In each case, crystals were mounted on a glass fiber or MiTeGen loop using Paratone oil, then placed on the diffractometer under a nitrogen stream. Low temperature $(100 \mathrm{~K}) \mathrm{X}$-ray data were obtained on a Bruker KAPPA APEXII CCD based diffractometer (Mo fine-focus sealed X-ray tube, $\mathrm{K}_{\alpha}=$ $0.71073 \AA$ ) or a Bruker D8 VENTURE Kappa Duo PHOTON 100 CMOS based diffractometer (Mo $\mathrm{I}_{\mu} \mathrm{S}$ HB micro-focus sealed X-ray tube, $\mathrm{K}_{\alpha}=0.71073 \AA$ ). All diffractometer manipulations, including data collection, integration, and scaling were carried out using the Bruker APEXII or APEXIII software. ${ }^{5-6}$ Absorption corrections were applied using SADABS. ${ }^{7}$ Space groups were determined on the basis of systematic absences and intensity statistics and the structures were solved in the Olex 2 software interface ${ }^{8}$ by intrinsic phasing using XT (incorporated into SHELXTL) ${ }^{9}$ and refined by full-matrix least squares on $\mathrm{F}^{2}$. All non-hydrogen atoms were refined using anisotropic displacement parameters. Hydrogen atoms were placed in the idealized positions and refined using a riding model, unless noted otherwise. The structure was refined (weighed least squares refinement on $\mathrm{F}^{2}$ ) to convergence. Graphical representation of structures with 50\% probability thermal ellipsoids were generated using the Crystal Maker X visualization software.

Table S1. Crystal and refinement data for complexes $\mathbf{5 , 6}$, and $\mathbf{9}$.

\begin{tabular}{|c|c|c|c|}
\hline & 5 & 6 & 9 \\
\hline CCDC Number ${ }^{10}$ & 2091817 & 2091815 & 2091816 \\
\hline Empirical formula & $\mathrm{C}_{41} \mathrm{H}_{53} \mathrm{MoO}_{2} \mathrm{P}_{2}$ & $\mathrm{C}_{36} \mathrm{H}_{48} \mathrm{MoP}_{2} \mathrm{Si}$ & $\mathrm{C}_{43} \mathrm{H}_{52} \mathrm{MoOP}_{2} \mathrm{~S}$ \\
\hline Formula weight & 735.71 & 666.71 & 774.78 \\
\hline $\mathrm{T}(\mathrm{K})$ & 100 & 100 & 100 \\
\hline$a, \AA$ & $14.939(4)$ & $9.8613(4)$ & $13.2942(13)$ \\
\hline$b, \AA$ & $14.781(2)$ & $19.1509(8)$ & $12.9633(13)$ \\
\hline$c, \AA$ & $17.032(4)$ & $18.1822(8)$ & $22.396(2)$ \\
\hline$\alpha, \circ$ & 90 & 90 & 90 \\
\hline$\beta,{ }^{\circ}$ & $97.488(10)$ & $105.215(2)$ & $99.288(5)$ \\
\hline$\gamma,{ }^{\circ}$ & 90 & 90 & 90 \\
\hline Volume, $\AA^{3}$ & $3728.9(14)$ & $3313.4(2)$ & $3809.1(7)$ \\
\hline $\mathrm{Z}$ & 4 & 4 & 4 \\
\hline Crystal system & Monoclinic & Monoclinic & Monoclinic \\
\hline Space group & $\mathrm{P} 2_{1} / \mathrm{n}$ & $\mathrm{P} 2{ }_{1} / \mathrm{n}$ & $\mathrm{P} 2_{1} / \mathrm{c}$ \\
\hline$d_{\text {calc }}, \mathrm{g} / \mathrm{cm}^{3}$ & 1.310 & 1.337 & 1.351 \\
\hline$\theta$ range, ${ }^{\circ}$ & 2.750 to 38.190 & 2.127 to 46.189 & 1.821 to 42.221 \\
\hline$\mu, \mathrm{mm}^{-1}$ & 0.471 & 0.552 & 0.516 \\
\hline Abs. Correction & Semi-empirical & Semi-empirical & Semi-empirical \\
\hline GOF & 1.228 & 1.024 & 1.021 \\
\hline$R_{1},{ }^{a} w R_{2}{ }^{b}[\mathrm{I}>2 \sigma(\mathrm{I})]$ & $0.0514,0.1031$ & $0.0523,0.1220$ & $0.0364,0.0691$ \\
\hline Radiation Type & Mo $\mathrm{K}_{\alpha}$ & $\mathrm{Mo} \mathrm{K}_{\alpha}$ & Mo $\mathrm{K}_{\alpha}$ \\
\hline
\end{tabular}

${ }^{\mathrm{a}} \mathrm{R}_{1}=\sum|| \mathrm{F}_{\mathrm{o}}|-| \mathrm{F}_{\mathrm{c}}|| \sum\left|\mathrm{F}_{\mathrm{o}}\right| \cdot{ }^{\mathrm{b}}{ }_{\mathrm{w}} \mathrm{R}_{2}=\left[\sum\left[\mathrm{w}\left(\mathrm{F}_{\mathrm{o}}{ }^{2}-\mathrm{F}_{\mathrm{c}}{ }^{2}\right)^{2}\right] / \sum\left[\mathrm{w}\left(\mathrm{F}_{\mathrm{o}}{ }^{2}\right)^{2}\right]^{1 / 2}\right.$. 


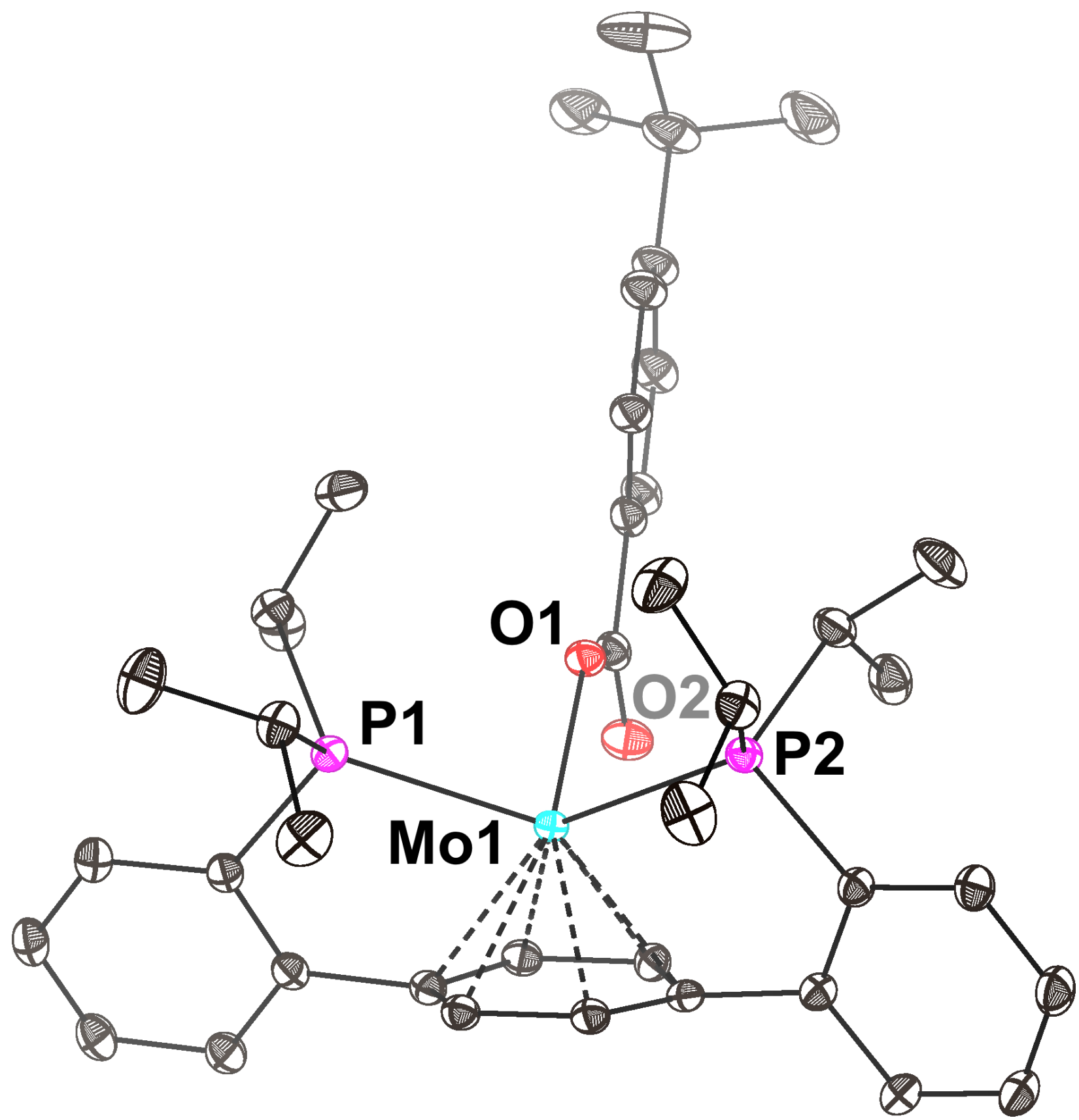

Figure S26. Solid-state structure of $\mathbf{5}$ with thermal anisotropic displacement ellipsoids shown at the 50\% probability level. Hydrogen atoms have been omitted for clarity. 


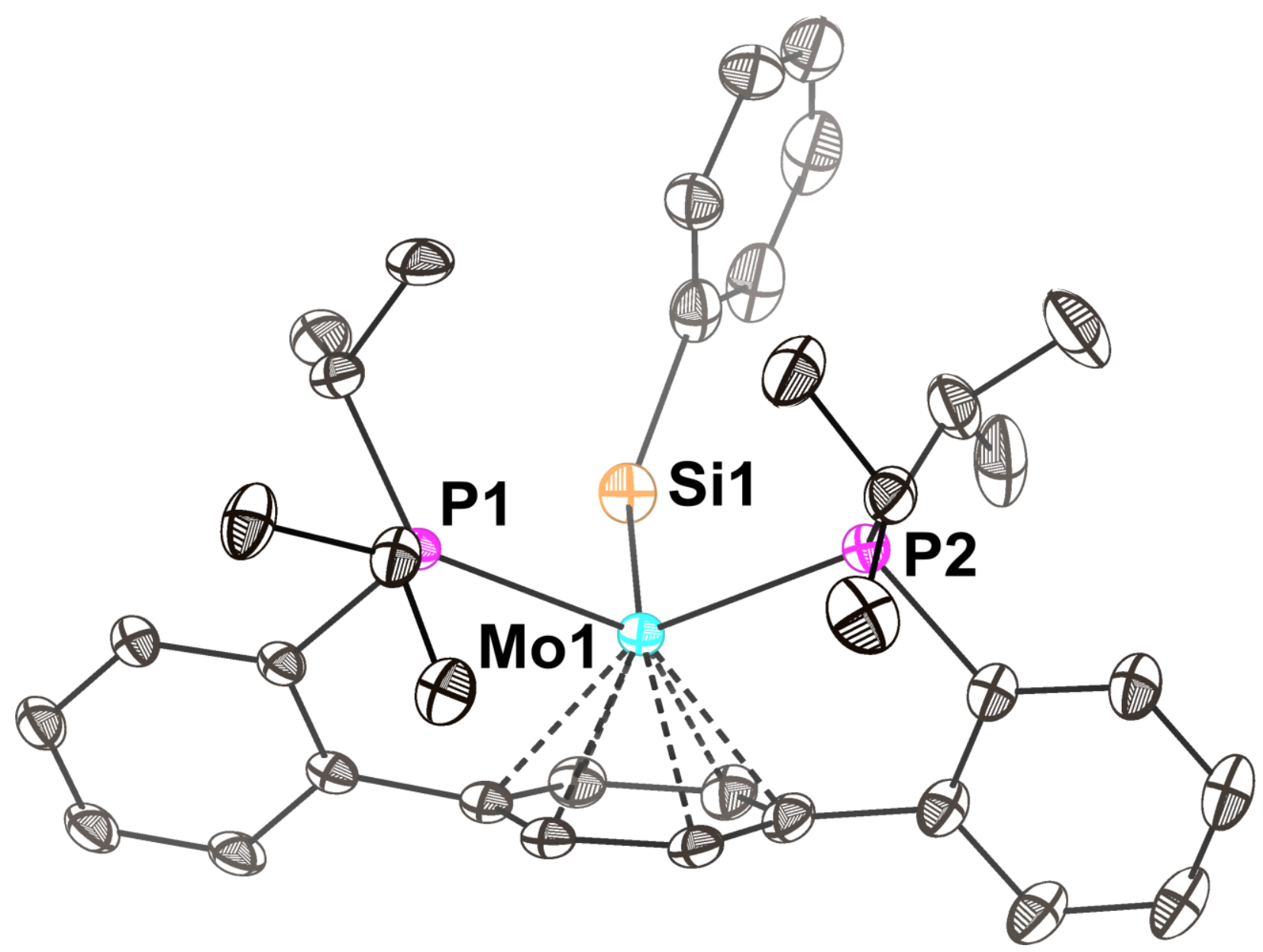

Figure S27. Solid-state structure of 6 with thermal anisotropic displacement ellipsoids shown at the 50\% probability level. 


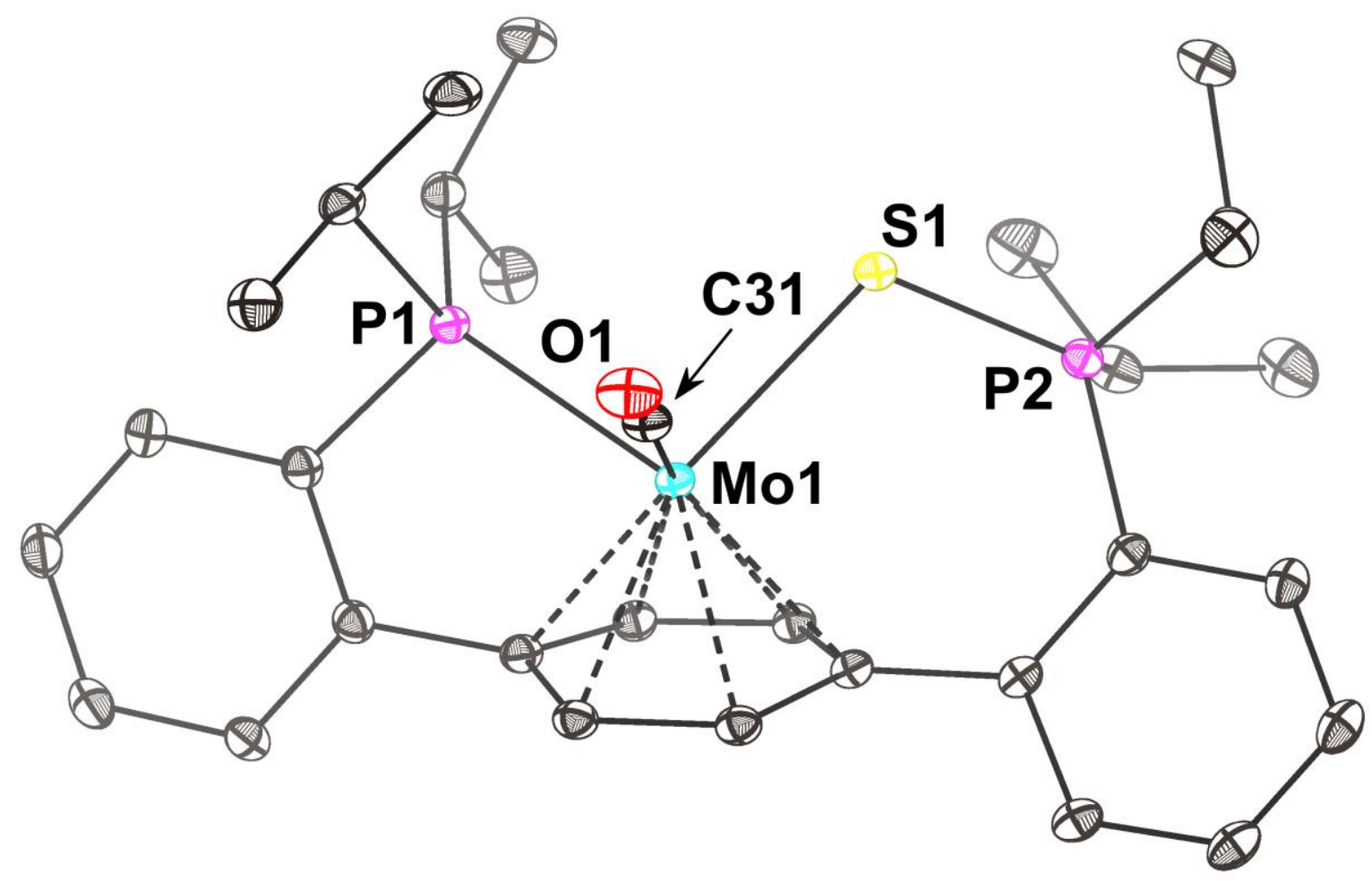

Figure S28. Solid-state structure of 9 with thermal anisotropic displacement ellipsoids shown at the 50\% probability level. Hydrogen atoms have been omitted for clarity. 


\section{References}

1. Pangborn, A. B.; Giardello, M. A.; Grubbs, R. H.; Rosen, R. K.; Timmers, F. J. Safe and Convenient Procedure for Solvent Purification. Organometallics 1996, 15, 1518-1520.

2. $\quad$ Buss, J. A.; Edouard, G. A.; Cheng, C.; Shi, J.; Agapie, T. Molybdenum Catalyzed Ammonia Borane Dehydrogenation: Oxidation State Specific Mechanisms. J. Am. Chem. Soc. 2014, 136, 1127211275 .

3. Buss, J. A.; Vandervelde, D. G.; Agapie, T. Lewis Acid Enhancement of Proton Induced $\mathrm{CO}_{2}$ Cleavage: Bond Weakening and Ligand Residence Time Effects. J. Am. Chem. Soc. 2018, 140, 1012110125.

4. $\quad$ Fulmer, G. R.; Miller, A. J. M.; Sherden, N. H.; Gottlieb, H. E.; Nudelman, A.; Stoltz, B. M.; Bercaw, J. E.; Goldberg, K. I., NMR Chemical Shifts of Trace Impurities: Common Laboratory Solvents, Organics, and Gases in Deuterated Solvents Relevant to the Organometallic Chemist. Organometallics 2010, 29, 2176-2179.

5. APEX2, Version 2 User Manual, M86-E01078, Bruker Analytical X-ray Systems, Madison, WI, June 2006.

6. APEX3, Version 1 User Manual, M86-EXX229, Bruker Analytical X-ray Systems, Madison, WI, May 2016.

7. Sheldrick, G.M. "SADABS (version 2008/1): Program for Absorption Correction for Data from Area Detector Frames", University of Göttingen, 2008.

8. Dolomanov, O. V.; Bourhis, L. J.; Gildea, R. J.; Howard, J. A. K.; Puschmann, H. OLEX2: A Complete Structure Solution, Refinement and Analysis Program. J. Appl. Cryst. 2009, 42, 339-341.

9. Sheldrick, G.M. A Short History of SHELX. Acta Cryst., 2008, A64, 112-122.

10. Crystallographic data have been deposited at the CCDC, 12 Union Road, Cambridge CB2 1EZ, UK and copies can be otained on request, free of charge, by quoting the publication citation and the respective deposition numbers. 